NBER WORKING PAPER SERIES

\title{
THE IMPACT OF THE TERMS OF TRADE ON \\ ECONOMIC DEVELOPMENT IN THE PERIPHERY, 1870-1939: VOLATILITY AND SECULAR CHANGE
}

\author{
Christopher Blattman \\ Jason Hwang \\ Jeffrey G. Williamson \\ Working Paper 10600 \\ http://www.nber.org/papers/w10600 \\ NATIONAL BUREAU OF ECONOMIC RESEARCH \\ 1050 Massachusetts Avenue \\ Cambridge, MA 02138 \\ June 2004
}

We acknowledge the superb research assistance of Martin Kanz. We are also greatly indebted to Luis Bértola, Michael Clemens, John Coatsworth, and Yael Hadass for their help in constructing the underlying data base for other projects with Williamson. We are also grateful to them and to Brad Delong, Chang-Tai Hsieh, Michael Jansson, Ian McLean, Edward Miguel, Kevin O'Rourke, Leandro Prados, Martha Olney, and seminar participants at Harvard University and University of California Berkeley for comments. Blattman and Hwang thank the Harvard Center for International Development and the National Bureau of Economic Research for office space and computing resources. Williamson thanks the National Science Foundation for support under NSF grant SES-0001362. The views expressed herein are those of the author(s) and not necessarily those of the National Bureau of Economic Research.

(C2004 by Christopher Blattman, Jason Hwang, and Jeffrey G. Williamson. All rights reserved. Short sections of text, not to exceed two paragraphs, may be quoted without explicit permission provided that full credit, including $\odot$ notice, is given to the source. 
The Impact of the Terms of Trade on Economic Development in the Periphery, 1870-1939:

Volatility and Secular Change

Christopher Blattman, Jason Hwang, Jeffrey G. Williamson

NBER Working Paper No. 10600

June 2004

JEL No. F1, N10, O1

\section{$\underline{\text { ABSTRACT }}$}

Most countries in the periphery specialized in the export of just a handful of primary products for most of their history. Some of these commodities have been more volatile than others, and those with more volatile prices have grown slowly relative both to the industrial leaders and to other primary product exporters. This fact helps explain the growth puzzle noted by Easterly, Kremer, Pritchett and Summers more than a decade ago: that the contending fundamental determinants of growth - institutions, geography and culture - exhibit far more persistence than do the growth rates they are supposed to explain. Using a new panel database for 35 countries, this paper estimates the impact of terms of trade volatility and secular change on country performance between 1870 and 1939. Volatility was much more important for accumulation and growth than was secular change. Additionally, both effects were asymmetric between Core and Periphery, findings that speak directly to the terms of trade debates that have raged since Prebisch and Singer wrote more than 50 years ago. The paper also investigates one channel of impact, and finds that foreign capital inflows declined steeply where commodity prices were volatile.

Christopher Blattman Department of Economics University of California Berkeley, CA 94720 and NBER blattman@berkeley.edu
Jason Hwang

Department of Economics Harvard University Cambridge, MA 02138

jjhwang@fas.harvard.edu
Jeffrey G. Williamson Department of Economics Harvard University Cambridge, MA 02138

jwilliam@fas.harvard.edu 


\section{Introduction}

This essay explores an underappreciated aspect of long term growth: most countries outside Western Europe and the US have been specialized in the export of just a handful of commodities for most of their history; some of these commodities have proven more volatile than others; and those with more volatile primary product prices have grown slowly relative both to the industrial leaders and to other primary product exporters. Looking at nearly a century of price change, we draw a direct link between commodity price volatility and economic underdevelopment. Our findings are reminiscent of what Carlos Diaz-Alejandro (1984) called the "commodity lottery”. Each country's exportable resources, he explained, were determined in large part by geography and chance, and differences in later economic development were a consequence of the economic, political and institutional attributes of each commodity. We argue that the exogenous price volatility of each primary product mattered most by generating internal instability, reduced investment, and diminished economic growth.

Figure 1 charts income per head in 1939 against volatility in the terms of trade for 35 countries for the years 1870 to $1939 .{ }^{1}$ Volatility is measured as the standard deviation of departures from a slowmoving trend. ${ }^{2}$ The figure clearly depicts a negative correlation between terms of trade volatility and subsequent level of development, not just in the total sample but also within the subset of primary product-specialized countries traditionally known as the Periphery. Figure 2 charts 1939 income per head against the secular trend in the terms of trade. Within both the Periphery and the Core, we see a positive correlation between growth in the terms of trade and subsequent level of development.

We argue that the causation is much more likely to run from the terms of trade to growth rather than the other way around. Our terms of trade data are based on world market prices, and the primary producers in our sample are for the most part price-takers on the world market. Thus, secular changes and volatility in the terms of trade were exogenous events in the Periphery. This terms of trade evidence can shed light on three longstanding economic growth puzzles. First, although specialization in

\footnotetext{
${ }^{1}$ Here and throughout the paper we omit the World War I years. For a full account see section 3.
} 
the production and export of primary products has proven to be one of the most enduring and robust determinants of poor economic growth, ${ }^{3}$ economists have yet to account fully for the power of commodity-specialization in predicting economic performance. Second, economic performance among the resource-rich has varied enormously. In the last 150 years, some have grown remarkably fast (e.g. Canada and Norway), some have grown very slowly (e.g. Colombia and, until recently, India), while many lie somewhere in between (e.g. Turkey and Brazil). Clearly, primary product exporters were not created equal. Third, while such differences in long term economic performance are usually explained by the contending fundamental determinants of growth — namely institutions, geography and culture, these fundamentals exhibit far more persistence over time than do the growth rates they are supposed to explain. ${ }^{4}$

We suspect that an important determinant of growth has been overlooked in the contest between constitutions, cultures and coastlines. Observers regularly point to terms of trade shocks as a key source of macroeconomic instability in commodity-specialized countries, but they pay far less attention to the growth implications. ${ }^{5}$ In this essay, we exploit the long-term historical evidence to explore the hypothesis that exogenous shocks in the terms of trade can account for both the variance around fundamentals and the fundamentals themselves. Using a new database of global terms of trade for 35 countries over eight decades - a coverage of more than 85 percent of the world population and nearly all of world GDP in 1914 — we conclude that terms of trade volatility can explain the instability of growth rates, but more importantly that differences in price volatility can also help explain differences in long-term growth. Looking at the Periphery alone (the European Offshoots, Latin America, Asia and the Middle East), simple OLS estimates strongly suggest that between 1870 and 1939 a one standard deviation increase in terms of trade volatility was associated with a decrease in the rate of growth

\footnotetext{
${ }^{2}$ This trend was calculated using a Hodrick-Prescott filter as discussed in Section 2.

${ }^{3}$ For example, Sala-i-Martin (1997) or Sachs and Warner (2001).

${ }^{4}$ See Easterly, Kremer, Pritchett, and Summers (1993).

${ }^{5}$ For important exceptions, see Mendoza (1997), Deaton and Miller (1996), Kose and Reizman (2001), Bleaney and Greenway (2001), and Hadass and Williamson (2003).
} 
of GDP per capita of from 0.50 to 0.75 percent per annum, a decline robust to changes in the time period, volatility measure, and nations on the margin assigned to the Periphery category.

We also investigate one prime channel through which volatility could have impacted growthinvestment. Eichengreen (1996: 39, 72) has argued that countries in the Periphery experienced destabilizing shifts in international capital flows due to terms of trade shocks before and after WWI. He argues that negative terms of trade shocks depressed export revenues, and that capital inflows shrank as investment became less attractive. Current and capital account shocks thus reinforced one another, provoking financial crisis and inhibiting growth. We attempt to quantify this response. We examine a formal model in which a secular improvement in the terms of trade leads to higher levels of investment, and hence long-run economic growth, while higher volatility in the terms of trade reduces investment, and hence growth, because of aversion to risk. We then test the predictions of the model using the only reliable source of investment data for the period in question-British capital flows to the periphery from 1870 to 1913 . While we do not find evidence that secular changes in terms of trade influenced capital flows, volatility mattered. A one standard deviation increase in terms of trade volatility was associated with at least a 25 percent decrease in average capital flows to the Periphery. Our investment results are somewhat sensitive to specification, however, and so we conclude that while investment was clearly one channel of impact, volatility must have impacted growth along other channels as well.

Finally, we identify asymmetric effects between Core and Periphery. We observe higher average terms of trade growth and lower volatility in the Core. We also see that volatility was distinctly harmful to growth in the Periphery, but not so in the Core. It may be that rich countries with more sophisticated institutions and markets were better able to insure against price volatility than poor countries, so that terms of trade instability is likely to have had a far bigger negative impact in the Periphery than the Core. We also find asymmetry for the effects of secular terms of trade improvements. Since such positive price shocks should have reinforced comparative advantage, they should have induced more industrialization in the Core and less in the Periphery. If industrialization is the central carrier of 
growth, the terms of trade improvement should raise growth rates in the Core but lower them in the Periphery. This pattern is indeed the one we observe.

The remainder of this essay is organized as follows. Section 2 reviews some of the empirical and theoretical support for the relationship between the terms of trade and development, and makes the economics explicit. Section 3 presents the data. Our empirical strategy is described in Section 4, and the results are presented in Section 5. Section 6 concludes.

\section{Theory and Evidence on the Terms of Trade and Development}

In the introduction to his famous 1950 article, Hans Singer proposed that fluctuations in the terms of trade dramatically affected the funds available to poor countries for capital formation, and hence growth. Unfortunately for Singer, he missed an opportunity by failing to dwell on this point, and focused instead on the implications of a secular deterioration in the terms of trade.

The literature on the postulated secular deterioration is long and contentious. It is also, for the most part, immaterial, since from the longer backwards view in 2004 little trend appears to exist. In contrast, it was indeed possible to look back from 1950 and observe a downward drift in the commodity terms of trade. Along with Raoul Prebisch (1950), Singer argued that the fundamental nature of these commodities made it inevitable that primary product prices would fall relative to manufactures in the long run, and so the terms of trade and incomes of commodity exporters would decline over time. The "Prebisch-Singer thesis" has not survived the half century since they wrote, since we now think that structural breaks, serially correlated residuals, and unit roots may explain the patterns we see. ${ }^{6}$ Grilli and Yang (1988) analyze $20^{\text {th }}$ century commodity price data and find evidence of periodic structural breaks, but no trend. Bleaney and Greenaway (1993) contest this finding, and demonstrate the existence of a downward trend, but one of only -0.5 percent per annum. Such a trend, if it even exists, is very small relative to short term fluctuations, and so the remainder of this essay expects volatility to matter far more.

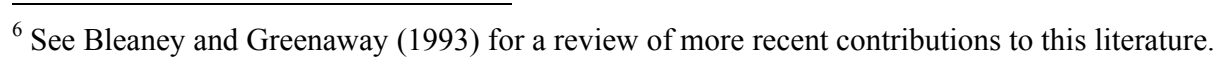


When thinking about fluctuations in the terms of trade, it will be useful to decompose annual disturbances in the terms of trade, or shocks, into the secular trend and the variance around this trend, which we call volatility. The literature has addressed the impact of all three types of terms of trade shocks on macroeconomic performance, although the distinction is seldom articulated.

\section{Terms of Trade Shocks and Short Run Macroeconomic Performance}

After several decades of debate, there is still no really well-articulated theory, let alone consensus, on the short run macroeconomic effects of terms of trade shocks.

One set of theories predicts a negative correlation between terms of trade improvements and growth, a relationship often referred to as the Resource Curse. Sachs and Warner $(1995,2001)$, for instance, have observed that resource-rich countries tend to grow more slowly than resource-poor countries. Yet no single resource curse theory is universally accepted. Sachs and Warner prefer the “crowding-out" logic, whereby primary production crowds out manufacturing activities. A political economy approach offers an alternative, usually relying on some form of government ineptitude or corruption. Krueger (1974) famously argued that rent-seeking was a growth-suppressing tendency of resource-owning elites in poor countries. Tornell and Velasco (1992) suggested that resource-rich developing countries have undeveloped property rights, so that gains are transferred to rich countries for safekeeping and terms of trade booms translate into capital flight.

Another set of theories claims that terms of trade improvements raise the value of output and the returns to investment in developing countries, and hence predict a positive correlation between those improvements and growth. Kose and Riezman (2001), for example, construct a stochastic, dynamic, two-sector model of a small open African economy. Terms of trade shocks have a direct effect on output since both sectors use imported goods as factors of production. In a numerical simulation of their model, trade shocks account for 45 percent of the variation in aggregate output and 86 percent of the variation in investment. Basu and McLeod (1992) develop a stochastic growth model in which imported inputs make production more efficient, but a drop in export prices make such inputs more 
costly and reduce output. They confirm that transitory terms of trade shocks have persistent effects on output levels in a sample of 12 primarily Latin American countries.

Empirical evidence from Africa seems to support the latter prediction rather than the resource curse one. Deaton and Miller (1996) employ vector autoregressions and find that a sudden 10 percent increase in commodity prices results in a 6 percent increase in output. Commodity price shocks account for much of the investment volatility in African economies as well. Deaton (1999) finds that a 12 percentage point increase in commodity prices in contemporary Africa adds 1.8 percentage points to the GDP per capita growth rate. While these results are specific to African economies after 1970, Deaton emphasizes that the same patterns can be observed for Egypt during the latter half of the 19th century. In fact, historical evidence from the Periphery suggests that the correlation between positive terms of trade shocks and output growth held throughout the $19^{\text {th }}$ and early $20^{\text {th }}$ centuries.

The analysis of such shocks is useful in illustrating the direct and immediate effects on GDP, but it does not identify the longer term impact on growth and development, and it fails to account explicitly for the difference between permanent and transitory changes in the terms of trade on growth. Accordingly, the literature has begun to investigate the role of short-range terms of trade trends on accumulation and long run growth.

\section{Terms of Trade Trends and Long Run Macroeconomic Performance}

The predicted relationship between terms of trade trends and economic development hinges on one's belief about the productivity of natural resource activities. Those who advocate the resource curse view argue that natural resource sectors are inherently unproductive, because, for example, they encourage rent-seeking behavior and fail to stimulate human capital accumulation. The alternative view typically ignores political economy considerations and assumes that natural resource activities generate the same externalities as do manufacturing activities. Mendoza (1997), for example, takes this more benign view in which an increase in the price of the commodity export increases the expected rate of return on investment in that sector, thus augmenting accumulation and growth economy- 
wide. Using cross-country panel regressions of 9 industrial and 31 developing countries from 1970 to 1991, he finds that an increase in the growth rate of the terms of trade by 1 percent raises the growth rate of consumption by 0.2 percent. Bleaney and Greenaway (2001) use Mendoza's model to analyze GDP per capita growth in 14 sub-Saharan countries between 1980 and 1995, finding that both growth and investment increase as the terms of trade improve.

Does such evidence spell doom for resource curse theories? Not quite. Hadass and Williamson (2003) find that terms of trade growth between 1870 and World War I reduced growth in a sample of commodity exporters, lending support to resource curse in the long run. Their sample, however, covers few of the developing countries that remained poor up to World War II, and they did not explore the influence of volatility. A larger sample of underdeveloped countries is needed to test for the influence of the terms of trade during the period that motivated the Prebisch-Singer debate in the first place.

\section{Terms of Trade Volatility and Economic Growth}

Most theories of terms of trade volatility also operate through the investment channel. ${ }^{7}$ The development literature offers an abundance of microeconomic evidence linking income volatility to lower investment in both physical and human capital. Households imperfectly protected from risk change their income-generating activities in the face of income volatility, diversifying and skewing towards low-risk alternatives with lower returns. ${ }^{8}$ Volatility can also result in suboptimal levels of investment in productive assets (Rosenweig and Wolpin 1993; Fafchamps 2004). Finally, severe cuts in health and education seem to follow from negative shocks to income - cuts that disproportionately affect children and hence long term human capital accumulation in poor countries. For example, it has been shown that negative income shocks caused large numbers of households to withdraw their children from school in Cote d'Ivoire and India (Jensen 2000; Jacoby and Skoufias 1997), while the recent In-

\footnotetext{
${ }^{7}$ Another smaller literature examines civil conflict as the channel through which terms of trade shocks affect long run growth. Rodrik (1999) offers one example. Miguel et al. (2004), however, find no relationship between the terms of trade and conflict in Africa over the last two decades. We plan to explore this issue in future papers.

${ }^{8}$ For a review, see Dercon (2004) and Fafchamps (2004).
} 
donesian financial crisis has been shown to have reduced enrollment and health expenditures (Frankenburg et al. 1999; Thomas et al. 2004).

Poor households cannot smooth their consumption and investments in the face of shocks because they are rationed in credit and insurance. So too on a macroeconomic scale-governments in the Periphery often find it difficult to borrow internationally, making it hard to smooth public investment and expenditure in the face of terms of trade shocks. ${ }^{9}$ Ramey and Ramey (1995) examine the macroeconomic volatility and growth correlation using data from 92 developing and developed economies between 1962 and 1985. They find that government spending and macroeconomic volatility are inversely related, and that countries with higher volatility have lower mean growth. Domestic and foreign investment should respond to such volatility.

We have already surveyed models where growth in the terms of trade leads to higher levels of investment because of higher returns. Likewise, higher volatility in the terms of trade should reduce investment and growth in the presence of risk aversion. The Mendoza model captures both features and it mimics the small, commodity-dependent exporting nation. It is a one-sector, stochastic endogenous growth model with risk-averse households who produce for export and consume imported goods. The terms of trade influences both the risk and return on domestic assets, and when risk-averse individuals cannot insure against terms of trade fluctuations, savings and growth are reduced.

Formally, households choose a consumption path that will maximize expected lifetime utility:

$$
U(C)=E\left[\sum_{t=0}^{\infty} \beta^{t} \frac{c_{t}^{1-\gamma}}{1-\gamma}\right] \quad \gamma>0,0<\beta<1,
$$

where $C_{t}$ is consumption of the imported good, $\beta$ is the subjective discount rate, and $\gamma$ is the intertemporal elasticity of substitution. Households maximize utility subject to the following period-by-period budget constraint:

\footnotetext{
${ }^{9}$ While greater volatility increases the need for international borrowing to help smooth domestic consumption, Catão and Kapur (2004) have shown recently that volatility constrained the ability to borrow between 1970 and 2001.
} 


$$
A_{t-1} \leq R_{t}\left(A_{t}-\frac{C_{t}}{z_{t}}\right)
$$

where $A_{t}$ is the stock of wealth in units of an exportable commodity in period $t, R_{t}$ is the stochastic rate of return realized each period that yields units of the exportable commodity that agents exchange for units of the importable good, and $z_{t}$ is the relative terms of trade (or the price of exports in terms of imports in world markets). $R_{t}$ and $z_{t}$ are non-negative random variables such that the effective rate of return $r_{t}=R_{t} z_{t+1} / z_{t}$ follows a $\log$-normal i.i.d. distribution. Hence $\ln \left(r_{t}\right)$ has mean $\mu$ and variance $\sigma^{2}$.

Mendoza obtains closed form solutions for consumption and wealth, and demonstrates that consumption growth can be expressed as:

$$
\frac{C_{t+1}}{C_{t}}=(1-\lambda) r_{t}
$$

where $(1-\lambda)$ is the saving rate with respect to wealth, and it is a function of the mean and variance of the terms of trade:

$$
\lambda\left(\mu, \sigma^{2}\right) \equiv 1-\left(\beta \mu^{1-\gamma}\right)^{\frac{1}{\gamma}} \exp \left(-(1-\gamma) \frac{\sigma^{2}}{\gamma}\right)
$$

Since it is assumed that agents cannot insure against fluctuations in $r_{t}$, an increase in the volatility of the terms of trade (i.e., a mean-preserving increase in $\sigma^{2}$ ) leads to reduced savings and increased consumption if the coefficient of relative risk aversion, $\gamma$, is lower than 2. Growth in the terms of trade (an increase in $\mu$ ) has the opposite effect.

As Bleaney and Greenaway (2001) note, the strong predictions of the Mendoza model with respect to the impact of terms of trade trend on consumption growth do not necessarily carry over to output growth. Rather, the desired relationships between output growth and terms of trade trend and volatility demand that the coefficient of relative risk aversion $\gamma$ be less than 1 . Thus, the theory is ambiguous regarding the effects of trends and volatility of the terms of trade on growth and investment.

Even so, in samples over short time periods, the empirical evidence seems to support a negative impact of terms of trade volatility and a positive impact of terms of trade growth. Mendoza tests his 
predictions for 40 industrial and developing countries over the period 1971-1991. Using consumption growth as a proxy for economic growth, he confirms the predicted positive relationship between secular terms of trade improvements and economic growth. He also finds a significant negative relationship between growth and terms of trade volatility. For 14 sub-Saharan countries between 1980 and 1995, Bleaney and Greenaway (2001) also find that terms of trade volatility has a significant negative impact on growth in income per head and investment levels.

Mendoza's predictions also appear to be consistent with additional late $20^{\text {th }}$ century evidence. For 61 developing countries between 1975 and 1992, Turnovsky and Chattopadhyay (2003) find that an increase in the growth rate of the terms of trade has a weak positive effect on the mean growth rate of output while an increase in volatility has a strong negative effect on output growth. Their results hold for both high and low volatility sub-samples.

Although each of the above studies employs different measures of volatility and different developing country samples, their results are remarkably consistent. Each is limited to the 20 or 25 years after 1970, however, and so none of them can really speak to the long term. Short periods also constrain their ability to isolate volatility from trend. Since our data cover the 70 years after 1870 , our analysis does not suffer that limitation. Our longer time series also makes possible what we think is a better method of decomposing terms of trade shocks into trend and volatility.

\section{Discussion of the Data ${ }^{10}$}

Our analysis stretches over three twenty year periods - the rapid expansion of global commodity and capital markets from 1870 to 1889 , the maturation of global markets from 1890 to 1909 , and the tumultuous interwar years from 1920 to 1939. These periods were chosen because they represent episodes of global integration and disintegration when commodity prices converge (or diverge) world wide, inducing large terms of trade changes and economy-wide responses. The war decades are excluded due to the absence of data and to the gross distortions to trade and prices attributable to war

\footnotetext{
${ }^{10}$ A detailed Appendix lists the sources and method of construction of all the variables used in this paper.
} 
demands, blockades and skyrocketing transport costs. The years 1950 to 2000 are also excluded because radical changes in the composition of production and trade in the periphery make the use of a continuous terms of trade series less meaningful.

\section{Commodities and Prices}

Prebisch and Singer contended that primary products are alike in that they all tend to decline in price relative to manufactures, but their claim has proven difficult to support. We examine the price behavior of 42 commodities on world markets, primarily from the reputable UK Statist-Sauerbeck commodity price index and supplemented from a number of other sources. If anything, the most important feature of commodity prices over our 70 years — and hence the terms of trade of commodityspecialized countries - is not their long-term drift, but rather their volatility. Volatility across products varies by more than a factor of ten. To illustrate, Figure 3 depicts trend growth and volatility in the prices of 9 primary products over the three twenty-year periods. Commodity prices experienced the highest average growth and lowest volatility from 1890 to 1909 , and the highest volatility and slowest growth during the interwar years. Within each period, however, some primary products were very volatile (such as coffee or tobacco), while others were relatively stable (like wheat or iron). Note that volatility between commodities often differed by a factor of two or three, and in some cases by a factor of six or seven. What's more, while some commodity prices rose (such as tobacco or wool) others suffered sharp reversals (such as rubber, which was supplanted by cheaper synthetics in the interwar period). Since most countries specialized in a handful of commodities, such differences in price behavior translated into diverse country experience, or, as we noted above, what Diaz-Alejandro called the “commodity lottery” (Diaz-Alejandro 1984).

\section{Countries and Country Data}

We have collected new terms of data for 35 countries across six continents. We divide our sample into Core and Periphery nations, an allocation based on traditions in the historical development literature which relies on geography, endowments, economic structure, commodity dependence, and the 
level of development. Table 1 lists the countries, their GDP per capita, the share of their exports in primary products, their export concentration, and their export share in GDP. Our Periphery was mostly poor, commodity-specialized, and highly concentrated in one or two export products. There are fourteen countries in our Core, including four Industrial Leaders (France, Germany, the UK, and the USA), five European Industrial Latecomers (Austria-Hungary, Denmark, Italy, Norway, and Sweden), and five in what we call the European Periphery (Greece, Portugal, Serbia, Spain, and Russia). The Periphery numbers twenty-one, including eight in Latin America (Argentina, Brazil, Colombia, Chile, Cuba, Mexico, Peru, and Uruguay), ten in Asia and the Middle East (Burma, Ceylon, China, Egypt, India, Indonesia, Japan, the Philippines, Siam, and Turkey), and three rich European Offshoots (Australia, Canada, and New Zealand). Any division between Core and Periphery is of course somewhat arbitrary, but our results are generally robust to the allocation, in particular the relocation of the European Periphery or the European Offshoots.

\section{GDP per Capita and Capital Flows}

For most countries in our sample, the primary source of GDP per capita estimates (in 1990 \$US) is Maddison (1995). Since his developing country GDP estimates often begin only with 1900 or even 1913, estimates for earlier years must be obtained from supplementary sources, in particular backcasting from the Maddison 1900 or 1913 benchmarks by using estimates of real wage or output growth constructed by Jeffrey Williamson. Full details are available in the data Appendix. The doubtful quality of the GDP per capita growth estimates for some countries, and especially for the late $19^{\text {th }}$ century, implies that measured changes in GDP per capita over a decade or more are almost certainly more reliable than annual estimates. They will also give a better fix on long run effects. ${ }^{11}$ As long as the measurement errors are random, they should not, of course, bias our econometric estimates, but rather only raise standard errors.

\footnotetext{
${ }^{11}$ Decades were chosen to be the main unit of analysis in part to reduce measurement error in the dependent variable, in part to have a sufficient span of time over which to measure terms of trade trend and volatility, and to ensure there were sufficient observations to give the econometric tests power.
} 
Our international capital flow data are measured with far more precision. They refer to British capital exports for the period 1870 to World War I, and our country sample received 92 percent of it. We choose British capital exports as a measure of international capital flows for two reasons. First, it is available. ${ }^{12}$ Second, Britain was then the world's leading capital exporter, far exceeding the combined capital exports of its nearest competitors, France and Germany. Thus British capital was the dominant source of international capital for more than forty years. Clemens and Williamson (2004) document that this capital flowed to where it was more profitable - chasing natural resources, educated populations, migrants and young populations. We will explore the impact of exogenous terms of trade shocks on such flows.

\section{The Country Terms of Trade}

The net barter terms of trade is, of course, defined as the ratio of export to import prices. The US and six of our European countries have excellent terms of trade data, but this is not true of the rest. Thus, we constructed new terms of trade series for the remaining twenty-eight. ${ }^{13}$ Formally,

$$
\operatorname{TOT}_{i, t}=\frac{\sum_{j=1}^{J} p_{i, j, t} \cdot w_{i, j}}{\sum_{j=1}^{J} p_{j, t} \cdot w_{j}}
$$

for product $i$, country $j$, and period $t$. Note that we employ an international market price for both numerator and denominator, prices which have the advantage of greater accuracy and availability. ${ }^{14}$ More importantly, in the small country case (a definition that seems to capture our Periphery export-

\footnotetext{
${ }^{12}$ The data were originally collected by Leland Jenks and Matthew Simon, and then reported by Stone (1999). They were cleaned recently by Clemens and Williamson (2004).

${ }^{13}$ Given the extensive previous effort that has gone into the construction of existing US and the six European terms of trade series, we have opted to employ these terms of trade indices. These traditional indices have not necessarily been constructed using the same price sources and weighting schemes, and so are not strictly comparable to our indices constructed for the periphery. But since the primary object of our investigation is the Periphery, and the Core is considered for comparative proposes only, we do not think differences in terms of trade construction pose a serious problem. Moreover, construction techniques seem similar and hence fairly comparable.

${ }^{14}$ To the extent that transport costs and tariff rates change significantly over time, a country's terms of trade measured in home markets might have obeyed somewhat different laws of motion than ours having been measured in international markets. While our indices might not exactly represent domestic prices, we are confident that the two sources would yield very
} 
ers) changes in the world price of the commodity can be treated as exogenous shocks. Also note that the import index in the denominator is in fact a price index for extensively traded US manufactured goods. ${ }^{15}$ The same import price index has been used for all periphery countries since reliable countryspecific import mix data are not available for most periphery countries before World War I. ${ }^{16}$ Focusing our analysis on the purchasing power of a country's exports in terms of a common basket of manufactured products is actually advantageous in that we can isolate the between-country effect of relative commodity price movements on growth.

\section{Trend and Volatility in the New Terms of Trade Series}

Figure 4 displays the paths of the terms of trade by region, 1870 to 1939 . At first glance it may seem as though, looking backwards from their vantage point after WWII, Prebisch and Singer were right to argue a secular decline in the Periphery's terms of trade. Thus, over our seven decades there seems to be an upward drift for the Industrial Leaders and the European Industrial Latecomers, and a downward drift for Latin America and Asia and the Middle East. Such a conclusion, however, is and was premature. First, as Spraos (1980) noted, such a trend is very sensitive to the choice of time period, and when the series is extended beyond 1950 the downward in the Periphery's terms of trade disappears. Second, as we noted above, downward drift is not itself evidence of a trend. Time series tests fail to find evidence of a common deterministic trend. We cannot reject the presence of a unit root in two-thirds of the countries and, in countries where trends appear, they are generally small and certainly not universal to all primary product producers.

In short, our country terms of trade exhibit considerable year-to-year fluctuations, as well short term trend movements or cycles, but little long-term trend-bolstering our prior conjecture that terms

similar trends, especially after 1900 when the decline in ocean transport costs slowed down considerably (Shah Mohammed and Williamson 2004).

${ }^{15}$ The index is a weighted sum of the prices of textiles $(55 \%)$, metals $(15 \%)$, machinery (15\%), building materials $(7.5 \%)$, and chemicals and pharmaceuticals $(7.5 \%)$ from the US Department of Commerce Historical Statistics. US data are employed because continuous price indices for comparable goods are unavailable for any other country. We draw comfort from the fact that the US price index tracks very closely the British Board of Trade index of export prices, and terms of trade series constructed from the UK and US price indices have a correlation coefficient of 0.91 . 
of trade volatility mattered far more in the historical past than did long run trend. This conjecture accords well with Mendoza's model, as outlined in the previous section. Growth of the trend in the terms of trade and decreases in the variance around trend (i.e., volatility) each raise economic growth.

There are several options for decomposing terms of trade movements into trend and volatility. Mendoza employs the terms of trade growth rate and the standard deviation of the growth rate. There are three potential drawbacks to this approach. First, the growth rate of the terms of trade over a period of time (such as a decade) will be overstated if there is a positive shock in the tenth year, and understated if there is a negative shock. More volatile countries will thus be measured with less accuracy, leading to systematic measurement error. Second, a structural break or a discrete change in the rate of growth will register as both a change in trend and a change in volatility, potentially confusing the effects. Third, persistent shocks away from trend will result in a lower measure of volatility than a shock that returns to trend the following year. Shocks that persist for more than a year before returning to trend will register as volatility, since they remain deviations from measured trend. The standard deviation of the growth rate of the terms of trade, on the other hand, will instead register only the initial shock and its eventual return to trend as volatility. The more gradual and consistent the return to trend, the lower the volatility measure, and so shocks that die out slowly will register as less volatile, even though the distortion may be greater.

We would prefer measures of trend and volatility that do not relate in a systematic way to one another and that minimize the measurement error in the trend. A practical solution is to use a filter that produces a smooth trend and stationary deviations. The Hodrick-Prescott (HP) filter is a common choice, used by Basu and McLeod (1992) among others, ${ }^{17}$ and we employ it here. ${ }^{18}$ Over the 10 -year

\footnotetext{
${ }^{16}$ What data do exist, however, suggest that the assumption closely approximates reality. Moreover, Kose and Riezman (2001) suggest that the use of such a price index is superior to an import index when examining the effects of trade shocks, and that such an index exhibits similar levels of volatility compared with a pure terms of trade measure.

${ }^{17}$ Similar methodologies have been used by other authors to measure the variability in the terms of trade. Lutz (1994) for example removes a linear trend (in the log of the terms of trade) and uses the variance of the residuals as a measure of volatility. This strategy has the problem of generating large residuals and therefore large implied volatility when there are changes in slope or structural breaks. Turnovsky and Chattopadhyay (2003) measure volatility as the variance of residuals from estimating a first-order autoregressive process for the terms of trade. The results from this procedure may be sensitive to the exact specification used and it seems unlikely to us that the terms of trade series for different countries in our sample are
} 
intervals used in our analysis, the HP data filter and Mendoza's method generate very similar results. The correlations of growth rates and volatility produced by the two methods are .85 and .86 respectively, and our findings are robust to both.

\section{Empirical Strategy}

Our identifying assumption is that terms of trade shocks are exogenous. The Periphery countries in our sample are generally too small and their primary product export share in world supply is too little to affect world price. Moreover, we would expect violations of this assumption (e.g. Chile and copper) to cause our results to understate the predicted positive impact of the terms of trade on growth. For instance, if a negative shock to the supply of copper in Chile caused the world market price to rise just as copper output (and hence GDP) in Chile fell, there would be a negative correlation between the terms of trade trend and output growth, biasing the coefficient on trend growth downwards.

Following Mendoza (1997), we employ a very parsimonious empirical model, regressing average GDP per capita growth rates on average trend growth and volatility in the terms of trade alone. ${ }^{19}$ We do the same for our capital flow equations, regressing the level of capital flows on terms of trade growth and volatility. The assumed exogeneity of the terms of trade implies that adding additional control variables should not change the estimated impact of the terms of trade. We find this to be the case, and will see that the addition of conventional determinants of growth as controls (population, schooling, openness, and so forth) do not alter our results. However, we might expect that the effect of exogenous terms of trade shocks on output is an increasing function of the importance of trade to the economy, and so we test this proposition by interacting the growth rate of the terms of trade with the initial share of exports in GDP for each country.

equally well described by a single autoregressive process. In any event, there is a high correlation (.87) between our measure of volatility and an alternative measure calculated using Turnovsky and Chattopadhyay's methodology.

${ }^{18}$ We set the smoothing parameter in the HP filter at 300, which implies a relatively slow-changing trend. A more quickly changing trend (such as that achieved with a smoothing parameter of 100 or lower) does not materially affect our results.

${ }^{19}$ As noted above, Mendoza actually employed per capita consumption growth as a proxy for output growth. We do not have data on consumption, and so follow other authors in analyzing the effects on per capita GDP growth. 
The unit of observation is a decade, and thus the dependent variable is the average annual growth of GDP per capita over some decade. Similarly, our terms of trade growth measure is the percentage change in the trend in the terms of trend (calculated from the HP filter) over the decade, while volatility is measured by the standard deviation of departures from this trend ${ }^{20}$ All of our specifications include country and decade fixed effects in order to control for unobserved fundamentals that were also determining growth performance, fundamentals that are not the focus on this paper. Finally, all standard errors are heteroskedasticity-robust.

\section{Results}

\section{Terms of Trade and Growth of per Capita Income}

The impact of secular change and volatility in the terms of trade (henceforth TOT) are presented in Table 2. Results are displayed for the full seven decades (1870-1939) as well as for two sub-periods: the first global century from 1870 to 1909 and the interwar autarchic disaster from 1920 to $1939 .{ }^{21}$ The World War I decade is omitted throughout for the reasons discussed earlier. The results are reported separately for the Core and Periphery, making it possible to test the asymmetry hypothesis. We also report results with and without a term interacting TOT Trend Growth with export share of GDP to see whether the terms of trade impact was contingent upon the level of openness and export dependence. It seems reasonable that more export-oriented countries would respond more forcefully to external shocks. Export shares are taken from the first year of the decade to avoid problems of endogeneity.

The top half of Table 2 reports the regression estimates and hypothesis testing for the terms of trade effects. The bottom half of the table reports the quantitative and economic importance of these terms of trade effects. Thus, the bottom half of Table 2 reports the sample means and standard deviations of the independent variables, as well as their marginal impact. The latter is measured as the pre-

\footnotetext{
${ }^{20}$ We have experimented with alternative ways of measuring terms of trade growth and volatility. These results are in the appendix.

${ }_{21}$ The Periphery consists of 21 countries and we have data for every country and every decade, except for one countrydecade observation, giving us a sample of $125(=21 * 6-1)$. There are a few more missing observations from the interwar Core, leaving us with 79 observations instead of $84(=14 * 6)$ that would be available in a complete dataset.
} 
dicted change in output growth from a marginal increase in the independent variable. For terms of trade volatility, the marginal impact is just the coefficient estimate. Marginal impact is defined the same way for trend growth when there is no interaction term. When we introduce the interaction term, marginal impact is the sum of the coefficient estimates on TOT Trend Growth by itself and the interaction term, the latter multiplied by the mean of export share. Finally, the last rows of Table 2 show the predicted change in output from a one-standard-deviation increase in either the growth or volatility of the terms of trade, thus showing how a plausible change in independent variables would have influenced output.

To begin with, columns (1) and (2) strongly support the asymmetry hypothesis. Changes in secular trends in the terms of trade were significantly and positively associated with output growth in the Core, but not in the Periphery. Changes in volatility had a significant negative influence on income growth in the Periphery, but not in the Core. This asymmetry between industrial-exporting Core and primary-product-exporting Periphery continues to hold when we introduce an interaction term between TOT Trend Growth and export share in columns (3) and (4). The net effect of trend growth will be sorted out below in the marginal impact calculations, but it is interesting to note the signs. The negative sign on the linear term for the Periphery implies that terms of trade improvements in developing countries reduced output growth in that decade. However, the positive sign on the interaction term suggests that the negative effect was mitigated, perhaps entirely undone, by having a more open economy exporting a larger share of output. ${ }^{22}$ An increase in export share, holding constant concentration, may have acted as a foil to rent-seekers, or exerted a positive influence on output growth through various channels, such as efficiency gains or the development of better institutions. We also observe that including the interaction term improves the statistical significance on volatility.

When we restrict our attention to the period before World War I in columns (5) through (8), our main findings continue to receive strong support. Improvements in long-run trends in the terms of

\footnotetext{
${ }^{22}$ Note that we are holding fixed volatility in the terms of trade so we have in effect controlled for export concentration.
} 
trade affected output growth positively in the Core, but not in the Periphery, while volatility diminished growth in the Periphery, but not in the Core. When we restrict our attention to the interwar period in columns (9) through (12), we are left with a much smaller sample (23 observations in the Core and 41 in the Periphery). As a result, standard errors are large and statistical significance low, but we note that the point estimates are generally consistent with those found for the pre-war period. It seems reasonable, therefore, to conclude that the same forces were at work both before and after the war.

The economic effects of our estimates are big. A one-standard-deviation increase in TOT Trend Growth was associated with a 0.45 percentage point increase in the average annual growth rate of per capita GDP -- a big number given that the average annual growth rate in the Core was just 1.4 percent. A one-standard-deviation increase in trend growth is approximately equivalent to replacing the experience of France and Austria, which saw their terms of trade deteriorate modestly at -0.2 percent per annum, with that of Germany, which saw its terms of trade improve dramatically over the period at 0.8 percent per annum. It is also reassuring that the empirical magnitudes are very similar across all our specifications.

The economic effect of TOT Volatility in the Periphery was even bigger - a one-standarddeviation increase lowers output growth by nearly 0.6 percentage points (the magnitudes being very similar with and without the interaction term). To illustrate the impact, consider an example from the primary product-exporting Periphery. Per capita income in Canada grew faster than in Indonesia by about 1 percent per annum. The difference in terms of trade volatility between the two countries was just under one half of one standard deviation. Our estimates imply that if, through good fortune, Indonesia had experienced the smaller terms of trade volatility of Canada, then Indonesia would have grown faster by about 0.3 percentage points, reducing the growth rate gap between the two by a third.

These magnitudes suggest that terms of trade shocks were an important force behind the big divergence in income levels between Core and Periphery. The gap in growth rates in per capita income between Core and Periphery in our sample was 0.4 percentage points. If the Periphery had experienced the same terms of trade volatility as the Core (leaving the observed growth rate of the terms of trade 
unchanged), this would have added 0.2 percentage points to average GDP per capita growth rates in the Periphery. This alone erases half of the output per capita growth gap. If, in addition, the Core had experienced no secular improvement in the terms of trade, instead of the observed 0.36 percent per annum growth rate, this would have reduced output growth in the Core by 0.15 percentage points. Combined, these two eminently plausible counterfactuals - the proposed changes are less than one half of one standard deviation away from the means, would have eliminated nearly the entire gap in growth rates between Core and Periphery.

What were the channels of terms of trade impact? Here we investigate one possibility, capital accumulation financed by capital inflows, leaving further research on this question for future work. We have already noted that Britain was the paramount source of development capital during these years. We find that gross capital flows from Britain to Periphery countries were decreasing in TOT volatility (Figure 5). In Table 3, the dependent variable is log of the average capital inflows a country received from Britain over 10-year periods between 1870 and 1909. The specification in Table 3 is the same as that used for output in Table 2, and asymmetry is confirmed once more. Neither long-run changes nor volatility in the terms of trade seems to have been important in attracting British capital to other countries in the Core. In the Periphery, however, greater volatility reduced capital inflows from Britain. Whether the interaction term is present or absent, terms of trade volatility enters negatively and significantly in the Periphery equations at the ninety percent level, but it is not significant in the Core regressions. These results are significant at the 95 percent level when the European Periphery is included (see below), or when the identical regression is run on 5-year intervals rather than 10 -year ones (results not shown), increasing our confidence in investment flows as a channel of impact. It is worth noting that when we attempt to normalize capital inflows by examining capital flows per capita or as a share of GDP, we confirm the negative relationship between volatility and foreign investment, but the results are not statistically significant (results not shown).

What about the economic significance of these estimates? Column (2) suggests that a one-standard deviation increase in volatility reduced capital inflows by $0.25 \log$ points or 25 percent. In the absence 
of data on capital stocks, we cannot estimate whether the terms of trade impact on foreign capital flows translated into a big or small domestic capital accumulation response. Our guess, however, is that domestic savings were even more powerfully influenced by terms of trade shocks than were foreign capital flows.

\section{Robustness Checks}

We have checked and confirmed the robustness of our results with respect to the following: alternative methods of decomposing terms of trade series into trend and fluctuations, alternative CorePeriphery definitions, and alternative specifications including additional controls. These results are presented in Appendix tables.

First, in Table A1, we reproduce Table 2 using Mendoza's definitions of terms of trade growth and volatility - the growth rate of TOT and the standard deviation of the growth rate of TOT. The findings are remarkably similar-higher TOT growth and lower TOT volatility are both associated with improved economic growth. The results on volatility are only significant over the pre-WWI period, however, although the marginal and one-standard-deviation impact estimates of volatility on growth are almost identical to the estimates using the HP-filtered deviations. The estimated impact of TOT growth is much greater than that from our HP-filtered trend. As we noted above, Mendoza's decomposition confounds trend with volatility somewhat, and it seems reasonable to presume that this confounding drives the strength of the TOT growth impact observed in Table A1..$^{23}$

Second, in Table A2 we check to make sure that our results are robust to the use of alternatives to the HP filter with a smoothing parameter of 300 (a slow-moving trend). These include HP filter with a smoothing parameter of 100 (a relatively fast-moving trend) and an MA filter with a 7-year window. Volatility in both cases is measured as standard deviations of departures from trend. Our point esti-

\footnotetext{
${ }^{23}$ Consider that, in the event of a single-year positive terms of trade shock in the last year of the decade, the TOT growth rate by Mendoza would rise, but that using the HP-filter would not. To the extent that there is an immediate and direct increase in measured GDP in the year of the shock (because of the price effect), Mendoza's measure will be positively correlated with growth. To the extent that such shocks have little or no effect on long-term GDP growth, we should observe little correlation between it and the HP filter measure of TOT growth.
} 
mates are nearly identical, and while statistical significance suffers using the MA filter, the alternative HP filter is highly significant.

Third, since any choice of the Periphery is necessarily arbitrary, Tables A3 and A4 re-estimate Table 2 using alternative definitions of the Periphery. We see that whether the European Periphery or the European Offshoots are excluded from the Periphery sample, our central findings stand. Our point estimates actually strengthen our case in most instances.

Fourth, we check the robustness of the capital flow results. Tables A5 and A6 repeat the above robustness checks for the capital inflows regressions. In Table A5, we see that our point estimates are similar using HP filters with slow- and fast-moving trends, as well as using Mendoza's measure of volatility (although the results for the latter are not statistically significant). In Table A6, we see that the capital flows results are not robust to exclusion of the European Offshoots, probably in part because of the loss of observations, but also because the offshoots had both low volatility and were major destinations for British capital, and are hence influential observations. It is worth noting however that inclusion of the European Periphery in our definition of the Periphery increases both our point estimates and the statistical significance of the relationship.

Finally, while we do not show results from specifications which include additional controls, our results are robust to the addition of school enrollment rates, tariff rates, share of primary products in exports, population growth and lagged GDP. ${ }^{24}$ If the terms of trade shocks are indeed exogenous, then we would not expect the inclusion of such controls to affect our point estimates of TOT growth and volatility. This is indeed the case, corroborating our identifying assumption.

\section{Conclusions}

We have reconstructed nearly a century of terms of trade experience from 1870 to 1939 and assessed its impact on the economic performance of the industrial Core and the primary-product producing Periphery. As a result of a heavily concentrated export mix in most of the Periphery, secular trend

\footnotetext{
${ }^{24}$ These results are available on request.
} 
and volatility in the terms of trade varied spectacularly across countries, both depending on commodity specialization. Our analysis suggests that those terms of trade movements were an important determinant of country-specific growth performance. They were especially important in the Periphery where volatility in the terms of trade was particularly damaging to economic growth. The analysis suggests that had volatility been reduced by one standard deviation in the Periphery, it would have raised per capita income growth there by 0.5 percentage points per annum, erasing most of growth gap between Core and Periphery. These results are surprisingly robust to the use of alternative Periphery allocations, terms of trade growth and volatility measures, and time period.

What is especially notable about our results is the persistent identification of striking asymmetry between Core and Periphery. Where terms of trade volatility was present, it created a significant drag on output growth in the Periphery. This was not true of the Core-where it experienced the same high price volatility, it did not experience the same drag on growth. In addition, while the Core benefited greatly from a small but positive long-run terms of trade trend, positive trends - when they did appear-did not translate in to more growth in the Periphery, but rather less. Moreover, when we investigate one channel of terms of trade impact — the flow of investment funds from Britain — we find evidence that capital inflows were negatively influenced by terms of trade volatility in the Periphery, but not in the Core. While our capital flows results are not nearly as robust as our growth results, they still point to an important channel of impact. Other channels are likely to be of importance, however, such as the effect of terms of trade shocks on the incidence of civil conflict (Rodrik 1999). These alternative channels await further investigation.

The patterns we observe here raise a number of additional questions. Exactly what kind of insurance did the more industrial Core countries take out that allowed them to escape the damaging consequences of terms of trade instability, insurance that was not, apparently, available to primary product exporters in the Periphery? Did the industrial Core simply have better-developed mechanisms by which to insure against adverse shocks? Why was it that countries in the Periphery did not benefit when the terms of trade rose over the long-term, or suffer when they fell? Does this evidence support 
de-industrialization and resource curse effects? Finally, while we have taken each country's terms of trade to be exogenous, future work might be advised to explore the deeper question: What were the sources of the cross-product differences in terms of trade trends and volatility, and why did some primary products (and hence countries) experience great volatility in their terms of trade while others enjoyed more stability?

These questions will have to await future research, but we hope that it will dwell on country impact, the direction taken here. 


\section{References}

Basu, P. and McLeod, D., "Terms of Trade Fluctuations and Economic Growth in Developing Economies," Journal of Development Economics 37 (1992): 89-110.

Bidarkota, P.V. and Crucini, M.J., "Commodity Prices and the Terms of Trade," mimeo, 1998.

Blattman, C., Hwang, J.J. and Williamson, J.G., "The Terms of Trade and Economic Growth in the Periphery 1870-1938," NBER Working Paper 9940, National Bureau of Economic Research, Cambridge, Mass. (August 2003).

Bleaney, M. and Greenway, D., "Long-Run Trends in the Relative Price of Primary Commodities and in the Terms of Trade of Developing Countries," Oxford Economic Papers 45 (1993): 349-63.

Bleaney, M. and Greenway, D., "The Impact of Terms of Trade and Real Exchange Rate Volatility on Investment and Growth in Sub-Saharan Africa," Journal of Development Economics 65 (2001): 491-500.

Catão, L. and Kapur, S., "Missing Link: Volatility and the Debt Intolerance Paradox," unpublished (January 2004).

Clemens, M.A. and Williamson, J.G., "Wealth Bias in the First Global Capital Market Boom 18701913," Economic Journal 114 (April 2004): 311-44.

Deaton, A. and Miller, R.I., "International Commodity Prices, Macroeconomic Performance and Politics in Sub-Saharan Africa," Journal of African Economics 5 (1996): 99-191, Supplement.

Deaton, A., "Commodity Prices and Growth in Africa," Journal of Economic Perspectives 13 (Summer 1999): 23-40.

Dercon, S., Insurance Against Poverty, Oxford: Oxford University Press, 2004.

Diaz-Alejandro, C., "Latin America in the 1930s," in R. Thorpe (ed.), Latin America in the 1930s, London: Macmillan, 1984: pp. 17-49.

Easterly, W., M. Kremer, L. Pritchett, and Summers, L.H., "Good Policy or Good Luck? Country Growth Performance and Temporary Shocks," Journal of Monetary Economics 32 (1993): 459-83.

Eichengreen, B., Globalizing Capital: A History of the International Monetary System, Princeton: Princeton University Press, 1996.

Fafchamps, M., Rural Poverty, Risk and Development, Chattenham: Edward Elgar Publishers, 2004.

Frankenberg, E., Beegle, K., Sikoki, B., and Thomas, D., "Health, Family Planning and Well-being in Indonesia during an Economic Crisis: Early results from the Indonesian Family Life Survey," Santa Monica, CA: RAND Labor and Population Program Working Paper Series 99-06, 1999.

Grilli, E. R. and Yang, M.C., "Primary Commodity Prices, Manufactured Goods Prices, and the Terms of Trade of Developing Countries: What the Long Run Shows," World Bank Economic Review 2 (1998): 1-48.

Hadass, Y. and Williamson, J.G., "Terms of Trade Shocks and Economic Performance 1870-1940: Prebisch and Singer Revisited," Economic Development and Cultural Change 51 (April 2003): 629-56.

Jacoby, H.G. and Skoufias, E., "Risk, Financial Markets, and Human Capital in a Developing Country," Review of Economic Studies 64 (July 1997): 311-35. 
Jensen, R., "Agricultural Volatility and Investments in Children," American Economic Review 90 (May 2000): 399-404.

Kose, M. A. and Reizman, R., "Trade Shocks and Macroeconomic Fluctuations in Africa," Journal of Development Economics 65(2) (1998): 55-80.

Krueger, A. O., "The Political Economy of the Rent-Seeking Society," American Economic Review 64 (June 1974): 291-323.

Lutz, M., "The Effects of Volatility in the Terms of Trade on Output Growth: New Evidence," World Development 22(12) (1994): 1959-75.

Maddison, A., Monitoring the World Economy 1820-1992, Paris: OECD Development Centre Studies, 1995.

Mendoza, E., "Terms of Trade Uncertainty and Economic Growth," Journal of Development Economics 54 (1997): 323-56.

Miguel, E., Satyanath, S. and Sergenti, E., "Economic Shocks and Civil Conflict: An Instrumental Variables Approach," forthcoming in Journal of Political Economy (2004).

Prebisch, R., The Economic Development of Latin American and Its Principal Problems, Lake Success, NY: United Nations, Department of Economic Affairs, 1950. Reprinted in Economic Bulletin for Latin America 7 (1962): 1-22.

Ramey, G. and Ramey, V.A., "Cross-country Evidence on the Link Between Volatility and Growth," NBER Working Paper 4959, National Bureau of Economic Research, Cambridge, Mass. (1995).

Rodrik, D., "Where Did all the Growth Go? External Shocks, Social Conflict and Growth Collapses," Journal of Economic Growth 4 (December 1999): 385-412.

Rosenweig, M.R. and Wolpin, K.I., "Credit Market Constraints, Consumption Smoothing, and the Accumulation of Durable Production Assets in Low Income Countries: Investments in Bullocks in India," Journal of Political Economy 101(2) (1993): 223-44.

Sachs, J. and Warner, A., "Economic Reform and the Process of Economic Integration," Brookings Paper on Economic Activity 1 (1997): 1-53

Sachs, J. and Warner, A., "The Curse of Natural Resources," European Economic Review 45 (May 2001): 827-38.

Sala-i-Matin, X., “I Just Ran Two Million Regressions," American Economic Review 87(2) (1997): 178-83.

Shah Mohammed, S. and Williamson, J.G., "Freight Rates and Productivity Gains in British Tramp Shipping 1869-1950," Explorations in Economic History 41 (April 2004): 172-203.

Singer, H.W., "The Distribution of Gains between Investing and Borrowing Countries," American Economic Review 40 (1997): 473-85.

Spraos, J., "The Statistical Debate on the Net Barter Terms of Trade between Primary Commodities and Manufactures," Economic Journal 90 (1980): 107-28.

Stone, I., The Global Export of Capital from Great Britain, 1865-1914, New York: St. Martin's Press, 1999.

Thomas, D., Beegle, K., Frankenberg, E., Sikoki, B., Strauss, J., and Teruel, G., "Education in a Crisis," Journal of Development Economics 74 (June 2004): 53-85.

Tornell, A. and Velasco, A., "The Tragedy of the Commons and Economic Growth: Why Does Capital Flow from Poor to Rich Countries?" Journal of Political Economy 100 (1992): 1208-31. 
Turnovsky, S.J. and Chattopadhyay, P., "Volatility and Growth in Developing Economies: Some Numerical Results and Empirical Evidence," Journal of International Economics 59 (2003): 267-95. 


\section{Data Appendix}

Most data used in this paper come from a novel database constructed by collaborations between Jeffrey Williamson and Luis BYrtola, Chris Blattman, Michael Clemens and Yael Hadass, often from primary sources at the Harvard library. This appendix does not attempt a thorough description of sources and methods used in collecting this evidence, since much of the data herein have appeared in previous publications and more detailed descriptions of sources and methods are available within them. Most data for the period 1870-1913 first appeared in Clemens and Williamson, "Wealth Bias in the First Global Capital Market Boom 1870-1913," Economic Journal 114 (April 2004): 311-44.. Most data for the period 1914-1940 first appeared in Clemens and Williamson, "Why Did the Tariff-Growth Correlation Reverse After 1950?" Journal of Economic Growth (2004 forthcoming). Data for the 8 Latin America countries, however, was updated and expanded by John Coatsworth and Williamson in "The Roots of Latin American Protectionism: Looking Before the Great Depression," A. Estevadeordal, D. Rodrik, A. Taylor and A. Velasco (eds.), FTAA and Beyond: Prospects for Integration in the Americas (Cambridge, Mass.: Harvard University Press, 2004), which has a complete listing of changes and additions. Note that several sources are used frequently in all this work. They are: Arthur S. Banks, CrossNational Time Series, 1815-1973, [Computer File] ICPSR ed. (Ann Arbor, Michigan: Inter-University Consortium for Political and Social Research, 1976), hereafter Banks (1976); Brian R. Mitchell, International Historical Statistics, Europe, 1750-1988 (New York: Stockton Press, 1992); Brian R. Mitchell, International Historical Statistics: The Americas, 1750-1988 (New York: Stockton Press, 1993); Brian R. Mitchell, International Historical Statistics: Africa, Asia \& Oceania, 1750-1993 (New York: Stockton Press, 1998). hereafter Mitchell.

\section{GDP and GDP per capita}

The units on this variable are 1990 US dollars per inhabitant of any age. For most countries, gross domestic product per capita (in 1990 US dollars) is taken from Angus Maddison, Monitoring the World Economy 18201992 (Paris: Development Center of the Organization for Economic Cooperation and Development, 1995).

GDP per capita estimates for 1870-1950 for Australia, Brazil, Canada, China, Denmark, France, Germany, India, Indonesia, Italy, Japan, Mexico, New Zealand, Norway, Portugal, Russia, Spain, Sweden, Siam, and the United States come from Angus Maddison, 1995, Monitoring the World Economy, 1820-1992, OECD, Paris. For countries not reported in Maddison (1995), GDP per capita is calculated by dividing a country's income (in 1990 US dollars) by population in every year. Sources of the population data have been described elsewhere in this appendix, and the sources of the income estimates follow.

Data for Argentina after 1890 come from Maddison op. cit. Before this date, GDP per capita is assumed to grow at the same year-on-year rate as the estimates of Argentine real wages found in Jeffrey G. Williamson, 1995, "The Evolution of Global Labor Markets since 1830: Background Evidence and Hypotheses," Explorations in Economic History, 32:141-196.

GDP per capita estimates for Austria-Hungary before 1914 come from David F. Good, 1994, "The Economic Lag of Central and Eastern Europe: Income Estimators for the Habsburg Successor States, 1870-1910," Journal of Economic History, 54(4)(December): 69-891. These are converted from 1980 to 1990 dollars using a GDP deflator obtained from the Bureau of Economic Analysis of the United States Department of Commerce (online at http://www.bea.doc.gov/bea/dn/gdplev.htm).

Data for Burma after 1900 come from Maddison op. cit. Before this date it is assumed that Burmese growth mirrored that of India.

Ceylon presented the most difficult data challenge in this category, as we are not aware of any published figures for GDP in Ceylon during this period. Campbell (Burnham O. Campbell, 1993 "Development Trends: A Comparative Analysis of the Asian Experience," in Naohiro Ogawa et al., eds., Human Resources in Development along the Asia-Pacific Rim, Oxford University Press, New York) has estimated that in 1914, GDP per capita in Ceylon was 1.95 times that of India. The same ratio had declined to 1.52 by 1948 according to United Nations Statistical Yearbook 1949-50 (New York: 1950), pp. 21-2 and 406. In the intervening years, 1914-1948, it is assumed that the ratio declined annually at a constant rate. Before 1914, it is assumed that real GDP per capita grew at the same rate as did the ratio of the real value of British colonial revenue from Ceylon to the population of the Island. A full series of annual nominal colonial revenues and population figures come from the 1905 and 1914 editions of the annual Ceylon Blue Book, a statistical publication of the colonial administration in Colombo. Some of these figures were recorded in rupees, and are converted to pounds sterling using conversion rates from Bryan Taylor II, 2000, Encyclopedia of Global Financial Markets, Global Financial Data, Los Ange- 
les, California (online at http://www.globalfindata.com). The resulting figures are converted to real pounds sterling using the deflator in McCusker op. cit.

Data for Chile after 1900 come from Maddison op. cit. Before this date it is assumed that Chile grew at the same year-on-year rate as did our estimates of Argentine GDP per capita.

Data for Colombia after 1900 come from Maddison op. cit. Before this date, it is assumed that that GDP per capita grew at an unweighted average of the growth rates for Mexico and Brazil between 1850 and 1900 given in Coatsworth op. cit.

Estimates for Cuba for 1850 and 1913 are based on estimates of Cuban GDP per capita relative to that of Mexico and Brazil presented in John H. Coatsworth, 1998, "Economic and Institutional Trajectories in Nineteenth-Century Latin America," in John H. Coatsworth and Alan M. Taylor, eds., Latin America and the World Economy Since 1800, Harvard University Press, Cambridge, Mass. An unweighted average of the figures implied by Coatsworth's proportion of our estimates for Mexico and Brazil is calculated for both years, and the intervening years estimated by geometric interpolation. For the years 1914-1950, Cuba's Net National Product in current year pesos comes from Mitchell (1993). These NNP values are converted to 1990 US dollars with the help of the peso-dollar exchange rate given in Taylor (2000) and the American historical consumer price index given in John McCusker, How Much Is That in Real Money (Worcester, Mass.: American Antiquarian Society, 1992), pp. 330-2.

Estimates for Egypt after 1900 come from Maddison. Before this date it is assumed that GDP per capita grew at the same year-on-year rate as did estimates of Egyptian real wages from Jeffrey Williamson, 2000, "Real wages and relative factor prices around the Mediterranean, 1500-1940," in Şevket Pamuk and Jeffrey G. Williamson, eds. The Mediterranean Response to Globalization Before 1950, Routledge, New York. For the years 1900-1950, a trend for Egyptian GDP per capita is calculated with the help of benchmark values given in Maddison (1995). Annual GDP per capita estimates are then calculated under the assumption that Egypt deviated from the Maddison-estimated Egyptian benchmark trend in the same way (percentage-wise) as Turkey did from her GDP per capita trend (after the civil war).

Data for Greece are estimated by projecting Maddison's (op. cit.) 1913 figure backwards, assuming the growth rate found in James Foreman-Peck and Pedro Lains, 2000, "European Economic Development: The Core and the Southern Periphery, 1870-1910," in Şevket Pamuk and Jeffrey G. Williamson, eds., The Mediterranean Response to Globalization Before 1950, Routledge, New York.

Data for Peru after 1900 come from Maddison op. cit. Before this date it is assumed that Peru grew at the same year-on-year rate as did our estimates of Argentine GDP per capita.

Data for the Philippines after 1900 come from Maddison op. cit. Before this date it is assumed that Philippine GDP per capita grew at the same year-on-year rate as our estimates for Siam.

Estimates for Serbia after 1890 come from Foreman-Peck and Lains, op. cit. Before 1890 GDP per capita is assumed to grow at the same year-on-year rate as it did between 1890 and 1913.

Estimates for Turkey after 1913 come from Maddison. Before this date it is assumed that GDP per capita grew at the same year-on-year rate as did estimates of Turkish real wages from Jeffrey Williamson, 2000, "Real wages and relative factor prices around the Mediterranean, 1500-1940," in Şevket Pamuk and Jeffrey G. Williamson, eds. The Mediterranean Response to Globalization Before 1950, Routledge, New York.

Data for Uruguay after 1882 comes from Maddison op. cit. Before this date it is assumed that Uruguay grew at the same year-on-year rate as did our estimates of Argentine GDP per capita. GDP for Uruguay is taken from Mitchell (1993) for the period 1935-1940. Annual GDP per capita estimates 1914-1934 are calculated by assuming that Uruguay deviated from her GDP per capita trend (between the benchmark years of 1914, found in Clemens and Williamson (2000), and 1935, found in Mitchell) in the same way that Argentina did.

Data for a small remaining number of missing years are geometrically interpolated.

\section{Terms of Trade Index (or the Net Barter Terms of Trade - NBTT)}

Existing data series were employed for the terms of trade for the US, the UK, France, Germany, Sweden, Italy and Austria. Terms of trade for Austria-Hungary after 1882 are found in Scott M. Eddie, 1977, "The Terms and Patterns of Hungarian Foreign Trade, 1882-1913," Journal of Economic History, 37(2)(June):329-358. An index for 1876-1882 is constructed from indices of the physical quanta and values of exports and imports given in Statistik des Auswärtigen Handels des Österreichisch-Ungarischen Zollgebiets im Jahre 1891, Statistischen Departement im K. K. Handelsministerium, Vienna, 1893, pp. LXVIII-LXIX. For the period 1865-1875 the same source reports only export and import values, not physical quanta. Since the quanta display extremely stable trends during 1876-1892 (unlike the values, which are subject to the vagaries of prices), the quanta for 1865- 
1875 are extrapolated assuming the same, stable growth rate observed on 1876-1892. Combining these estimates with the trade value figures given for 1865-1875 yield a ToT estimate for this period. Terms of Trade for France 1870-1896 come from Charles Kindleberger, 1956, The Terms of Trade: A European Case Study, MIT Technology Press, Cambridge, Table 2-1, pp. 12-13. This is linked to a series from 1896-1913 found in P. Villa, 1993, Une Analyse Macroéconomique de la France au XXeme Siècle, CNRS Editions, Monographies d'Économetrie, Paris, pp. 445-6. German ToT for the entire period come from Walther G. Hoffmann, 1965, Wachstum der Deutschen Wirtschaft seit der Mitte des 19 Jahrhunderts, Springer-Verlag, Berlin, Table 134, col. 1, p. 548. Italy's terms of trade with Great Britain are taken as a proxy for overall Italian terms of trade. The former are found in I. A. Glazier, V. N. Bandera, and R. B. Berner, 1975, "Terms of Trade between Italy and the United Kingdom 1815-1913," Journal of European Economic History, 4(1)(Spring): 5-48. Sweden's terms of trade are taken from Simon Kuznets, 1996 [originally published 1967], "Quantitative Aspects of the Economic Growth of Nations: X. Level and Structure of Foreign Trade: Long-Term Trends," reprinted in C. Knick Harley, ed. The integration of the world economy, 1850-1914, Volume 1, Elgar Reference Collection: Growth of the World Economy Series, Vol. 3. Cheltenham, U.K, Table 12, p. 150. United States ToT are from Jeffrey G. Williamson, 1964, American Growth and the Balance of Payments 1820-1913, University of North Carolina Press, Chapel Hill, North Carolina, Table B4, p. 262.

For the remaining countries, a NBTT series was calculated from original sources. Note that the NBTT is simply the ratio of export prices to import prices, each weighted appropriately. Mathematically,

$$
N B T T_{j t}=\frac{\sum p_{i j t}^{X} \cdot w_{i j}^{X}}{\sum p_{i t}^{M} \cdot w_{i}^{M}}
$$

for product $i$, country $j$, and period $t$. Note that in this formulation the numerator, the export price index, is country-specific while the denominator, the import price index, is not. This is a simplification employed in this paper due to (i) the limited quality and quantity of data on imports and import prices to countries in the periphery, and (ii) the similarity observed, in what records are available, between the composition of imports to developing countries. While detailed data on exports weights and prices are available for virtually all of the countries and all of the years in our sample, import data are much more limited. These limitations and their consequences are discussed below.

Export Weights. For the purposes of this study, export weights have been calculated by individual country using the current value of major commodity exports and fixed weights. The use of a fixed set of weights is essential for disentangling price from quantity movements. Of course, any such approach is fundamentally flawed, not least because over a long period of time the mix of major commodity exports can shift significantly. A compromise position was taken by changing the export weights at approximately 20 -year sub-periods. These subperiods are 1870-1890, 1890-1913, 1913-1929, and 1930-1950, and within these the weights are calculated using sample year data. Export values for major commodities for Canada, Brazil, Chile, Colombia, Cuba, Mexico, Paraguay, and Peru are taken from Mitchell, International Historical Statistics The Americas 1750-1993, p.506 ff. Table E3. The same data for Australia, Burma, Ceylon, Egypt, India, Indonesia, Japan, Philippines, Siam, Turkey and New Zealand come from Mitchell, International Historical Statistics Africa, Asia and Oceania 17501993, p.637 ff. Table E3. Main commodity exports for Denmark, Greece, Norway, Portugal, Spain and Sweden were calculated from Statistical Abstract for Principal and Other Foreign Countries, London 1876-1912 and Die Wirtschaft des Auslandes, Statistisches Reichsamt Berlin 1928.

Export Prices. Export prices are quoted in foreign markets (wherever possible, in the UK), rather than domestic ones. Wholesale Prices for Wheat, Maize, Rice, Beef, Butter, Sugar, Coffee, Tea, Iron, Copper, Tin, Lead, Coal, Cotton, Flax, Hemp, Jute, Wool, Silk, Hides, Nitrate, Palm Oil, Olive Oil, Linseed, Petroleum, Indigo and Timber are taken from Sauerbeck, Prices of Commodities and Precious Metals, Journal of the Statistical Society of London, vol. 49/3 September 1886 Appendix C, for the years 1860-85. Sauerbeck, Prices of Commodities During the Last Seven Years, Journal of the Royal Statistical Society, vol.56/2 June 1893 p.241 ff., for the years 1885-1892, Sauerbeck, Prices of Commodities in 1908, Journal of the Royal Statistical Society 72/1 Mar 1909 for the years 1893-1908. Sauerbeck, Wholesale Prices of Commodities in 1929, Journal of the Royal Statistical Society, vol. 93/2 p. $282 \mathrm{ff}, 1930$ for the years 1908-1929. Sauerbeck, Wholesale Prices of Commodities in 1916, Journal of the Royal Statistical Society, vol. 80/2 p. $289 \mathrm{ff}$. for the years 1908- 1916. Sauerbeck, Wholesale Prices in 1950, Journal of the Royal Statistical Society, vol. 114/3 1951, p. $417 \mathrm{ff}$. for the years 191650. Prices for Cocoa, Crude Oil, Rubber, Tobacco and Zinc are taken from Dodd, Historical Statistics of the United States from 1790-1970, University of Alabama Press. Prices for Fruits and Nuts 1880-1914 are taken from Critz, Olmsted and Rhode, International competition and the development of the dried fruit industry 1880- 
1930 table 8.2, in Pamuk and Williamson, 2000. Prices for Opium 1860-1906 Ahmad Seyf, Commercialization of Agriculture: Production and Trade of Opium in Persia, 1850-1906 Table 4, International Journal of Middle East Studies, 1984. Prices for Beans \& Bean Products were calculated from Liang-Lin, China's Foreign Trade Statistics 1864-1949, Harvard University Press 1974, p.80 ff.

Import Weights. A single set of import weights is employed for all countries in the sample. Import data, unlike that of exports, is almost uniformly poor, in particular in countries outside the European Core. Traditionally, studies of country terms of trade have compensated for this lack of data through the use of British export data as a proxy for the imports of less developed nations. This approach is undesirable given that the composition of British exports can hardly be considered representative of the imports of developing countries as a whole, and because the use of current-year weights means that movements reflect changes in composition, not just prices. As an alternative, however, we employ a fixed index of non-primary goods from US statistics. This import index, like the British one, is country invariant. In the end, the differences are not material; the two series are almost identical (probably due to the heavy content of metals and textiles in both indices). This US manufactured export statistic is a weighted sum of the prices of textiles (55\%), metals (15\%), machinery (15\%), building materials $(7.5 \%)$, and chemicals and pharmaceuticals $(7.5 \%)$. Obviously a fixed weighting for all developing nations is unrepresentative of their particular import mix (but while not representative of the specific import mix of the country, such a metric may be relevant for measuring the changing value of the country's exports versus a fixed package of manufactured products available for import. In this sense our terms of trade represent the purchasing power of local commodities in terms of rich-country goods.) Moreover, a review of each nation's external commerce documents turns up remarkably similar import compositions. For the years 1870-1900, import composition for Australia, Canada, Ceylon, India and New Zealand was examined from Statistical abstract for the several colonies and other possessions of the United Kingdom no.1-40, 1863-1902. Data for Burma comes from Terulo Saito and Lee Kin Kiong Statistics on the Burmese Economy, Singapore 1999 pp 177, table VII-4. Import weights for China, Denmark, Egypt, Greece, Japan, Norway, Portugal, and Russia were calculated from Statistical Abstract for Principal and Other Foreign Countries, London 1876-1912 no. 13. Data for the Philippines are taken from Quarterly Summary of Commerce of the Phillipine Islands, Washington 1908 p.27 for the year 1893. Import composition for Serbia before 1914 is recorded in Sundhaussen, Historische Statistik Serbiens 1834-1914, Munich 1989 pp. 352-355. Main imports for Turkey are calculated from Mulhall, Dictionary of Statistics, London 1892 p. 145, for the year 1888. For the years 1900-1940, import weights for Australia, Canada, Ceylon, India, New Zealand are calculated for several reference years from Statistical abstract for the several British self-governing dominions, colonies, possessions, and protectorates no.41-53, 1903-1915, Statistical abstract for the several British oversea dominions and protectorates no.54-59, 1917-1927, Statistical abstract for the British Empire no.60-68, 1929-1938, Statistical abstract for the British Commonwealth no.69-70, 1945-1947 and Statistical abstract for the Commonwealth (trade statistics) no.71-72, 1948-1951. Composition of main imports for reference years after 1900 for Argentina, Chile, Greece, Indonesia, Japan, Mexico, Norway, Portugal, Russia, Serbia, Spain, Siam, Uruguay comes from Die Wirtschaft des Auslandes 1900-1927, Berlin 1928. Data for Burma comes from Terulo Saito and Lee Kin Kiong Statistics on the Burmese Economy, Singapore 1999 pp 177, table VII-4. Data for the Philippines is taken from Foreign Commerce of the Phillipine Islands, Washington 1912-1913 for the reference years 1907, 1908 and 1910. Composition of main imports for Turkey was calculated from Annuaire Statistique, Republique Turque, vol.1 pp. 103, 106 vol. 3 pp. 313, 314 for the years 1923, 1926 and 1929.

Import Prices: US price series for textiles, metals, machinery, building materials, and chemicals and pharmaceuticals come from Dodd, Historical Statistics of the United States from 1790-1970, University of Alabama Press.

An Additional Note on Import and Export Price Data. UK and US prices are employed in the theory that the prices in these large, integrated and (in the UK, at least) unprotected markets would supply us with a relatively reliable "world" price index for each commodity group. A chief disadvantage of using such world price indices, however, is that home market prices in each country may diverge from the world ones in the short and even long term. This may be because of differences in product features and quality, because of variations in the composition of the products within a category, or because of less-than-perfect market integration combined with local market conditions and shocks. Kindleberger (1958) illustrates the wide divergence in the prices of bulky products such as coal and lumber between two markets as closely integrated as the US and UK. Another disadvantage of not using the home market price is the distortion created by changes in transport costs. One would prefer a terms of trade measure that is independent of transport costs. In a moment we will discuss the adjustments made to our terms of trade figures to account for transport cost changes. Such adjustments as we can make, however, cannot truly represent actual freight-adjusted prices. Overall, though, we feel the advan- 
tages of employing world price indices outweigh these disadvantages. First and foremost, home market prices are not typically on hand for the periods and countries in question. Rather, only the somewhat less desirable unit prices (calculated as the value of imports divided by the volume) are available. Second and more important, we believe UK and US market prices to be more reliable, accurate and comparable given the quality of reporting (at the time) and the quality of scholarship on these prices since then. Third, to the extent that commodity markets are well integrated worldwide, the UK and US market prices should approximate the world price. This is especially true because we are interested in price changes, not levels. To the extent that UK and US prices move in similar directions and similar magnitudes to prices in the rest of the world, these "world" price indices will more or less represent price changes relative to an index year in other nations. We believe this to be a reasonable and necessary assumption. Fourth, these foreign market price indices would have been available to (and probably used) by industrialists and policymakers throughout the period in question. Accordingly, for questions of policy response (and perhaps price setting) foreign market indices may be a more appropriate data source than home market ones. Fifth, the use of a world price index harmonizes and simplifies construction of the indices, enabling us to examine a wider sample of countries at the cost, perhaps, of precision. Fifth, by measuring both the export and import price indices in a common currency, we eliminate any inflationary bias from the figures. 
Figure 1:

1939 GDP per capita and Terms of Trade Volatility 1870-1939

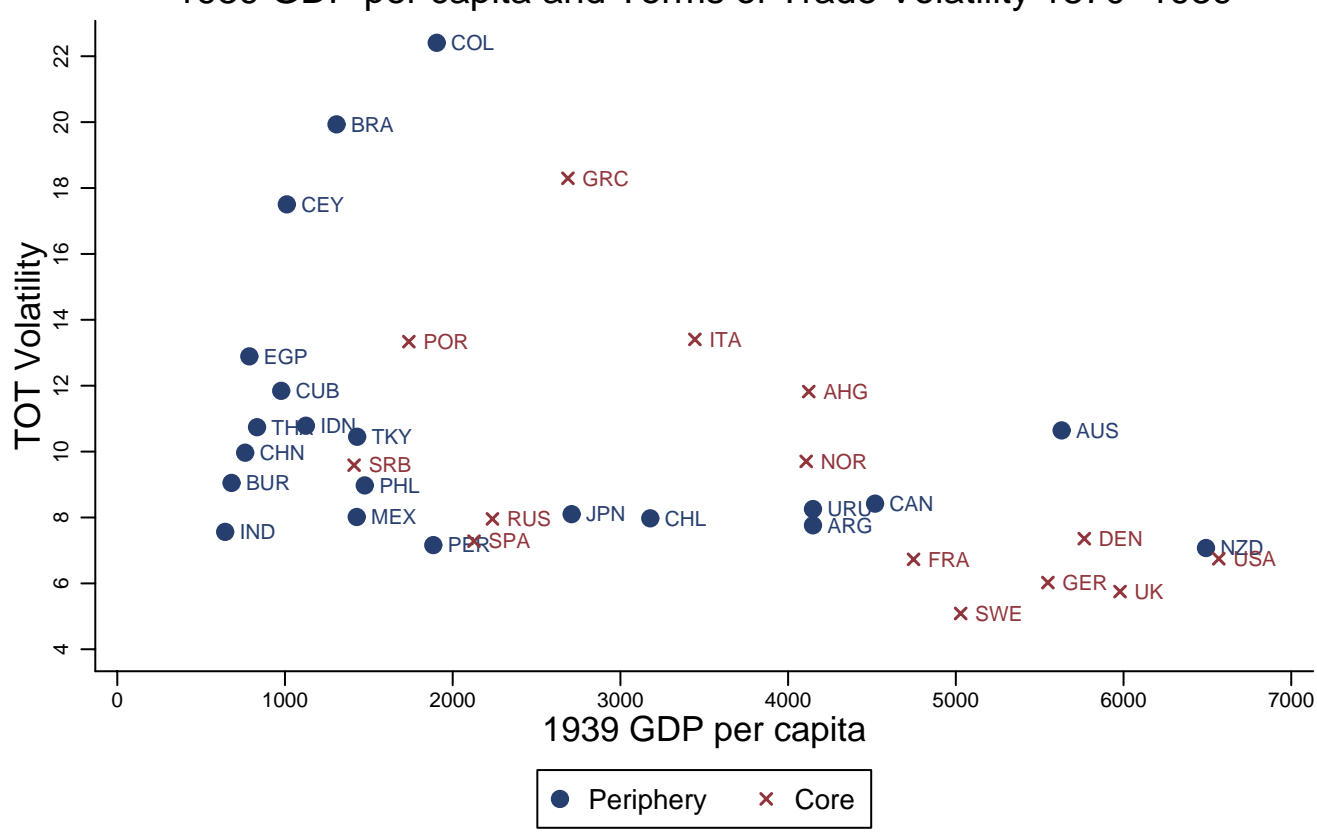

Figure 2:

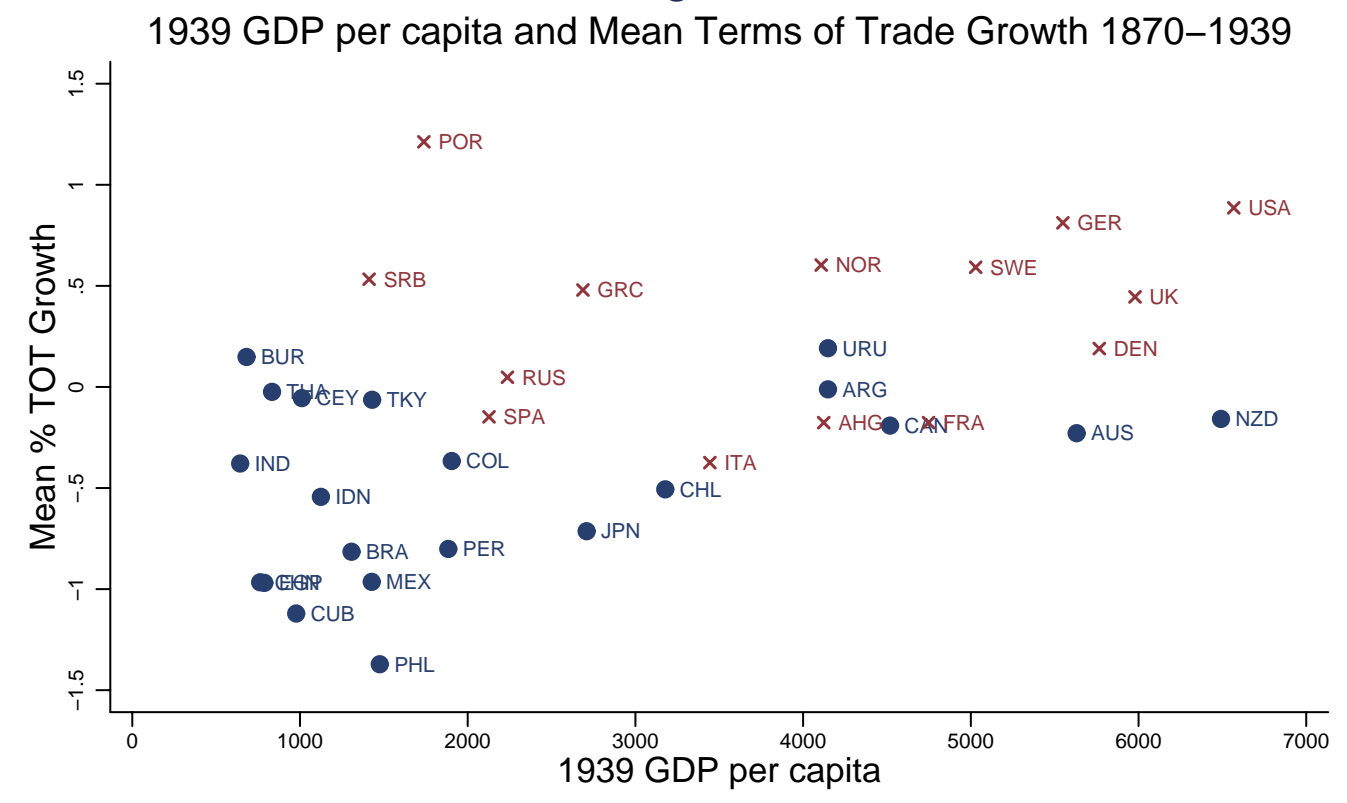

- Periphery $\times$ Core 
Figure 3:

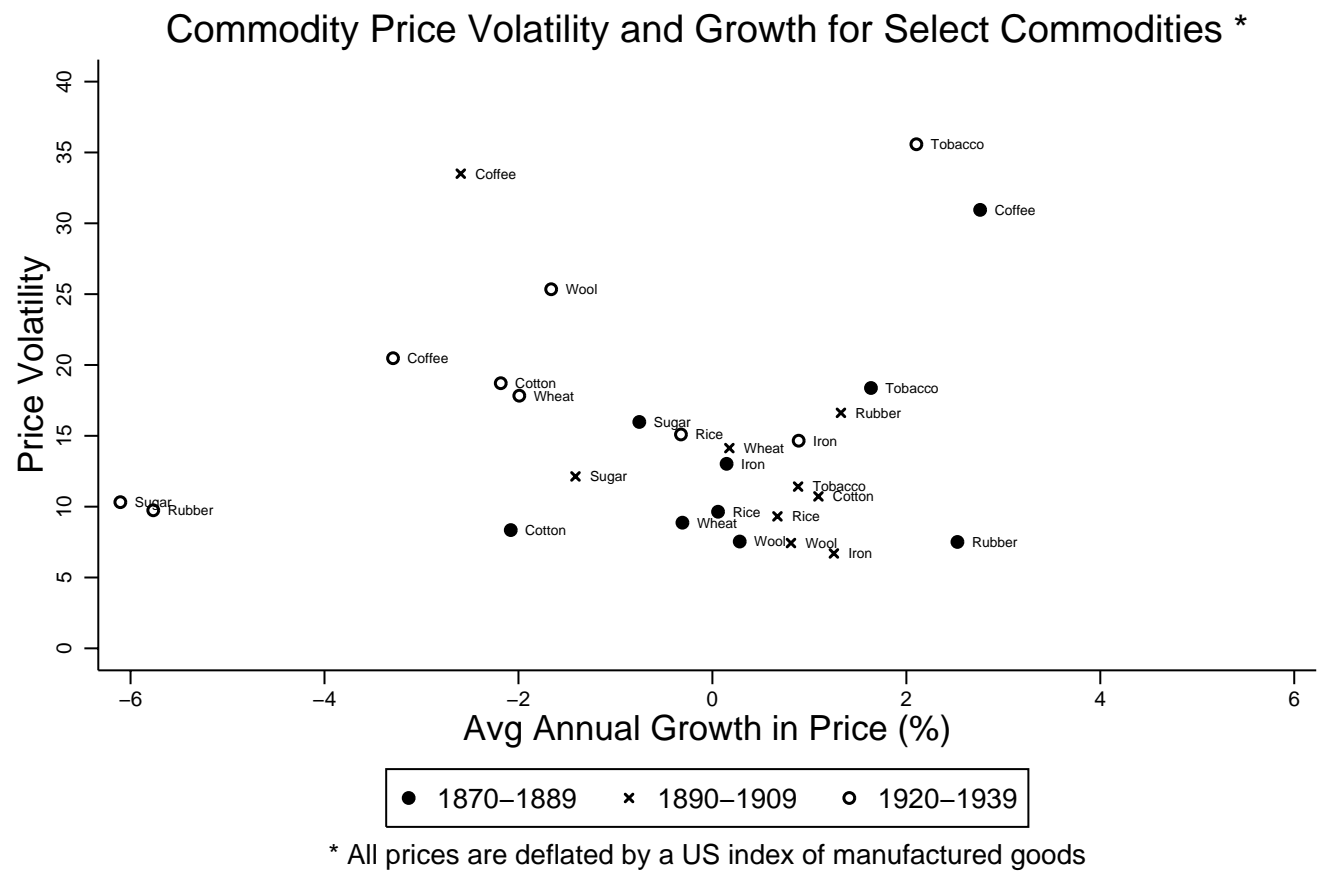



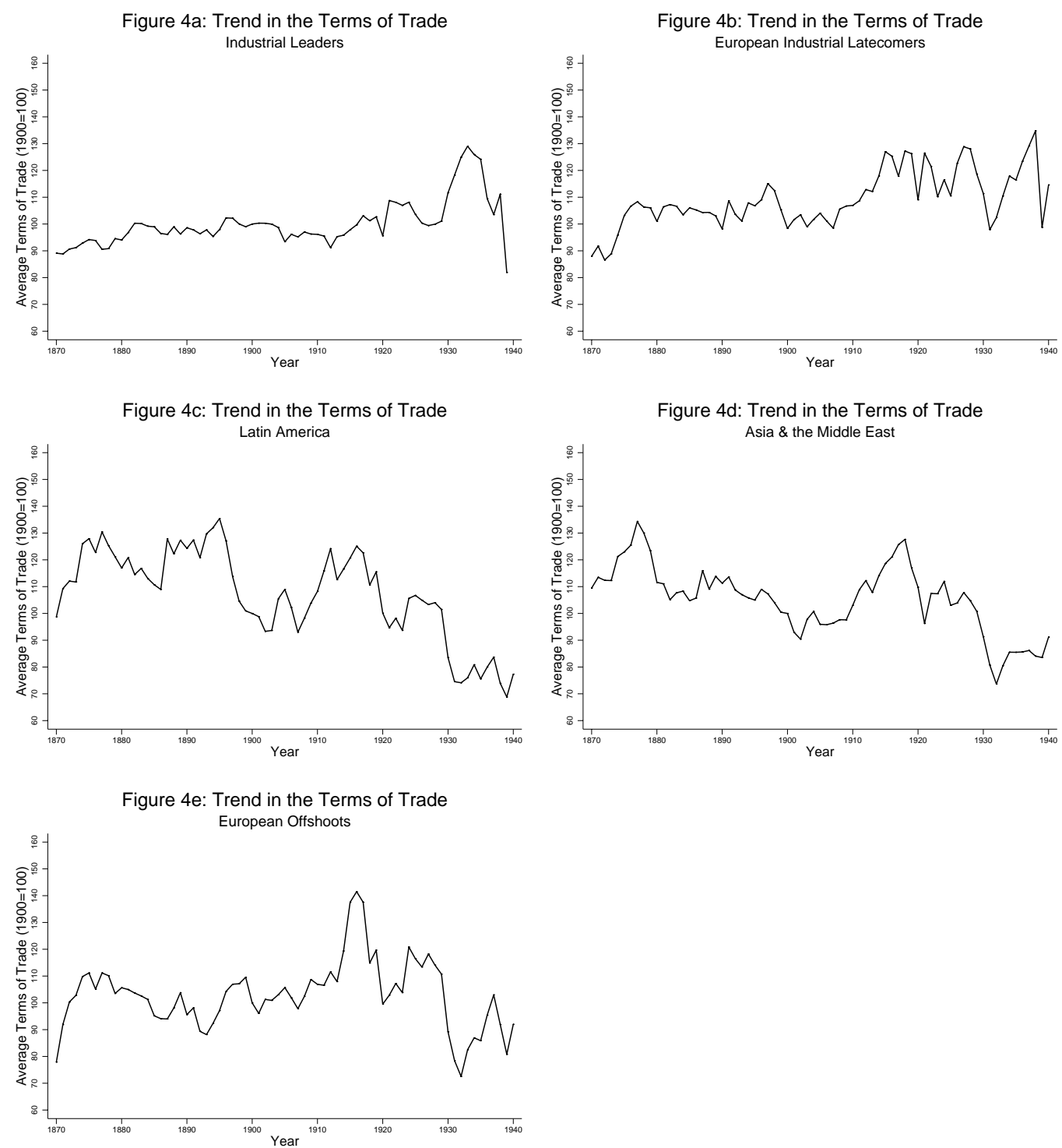
Figure 5: Capital Flows and Terms of Trade Volatility

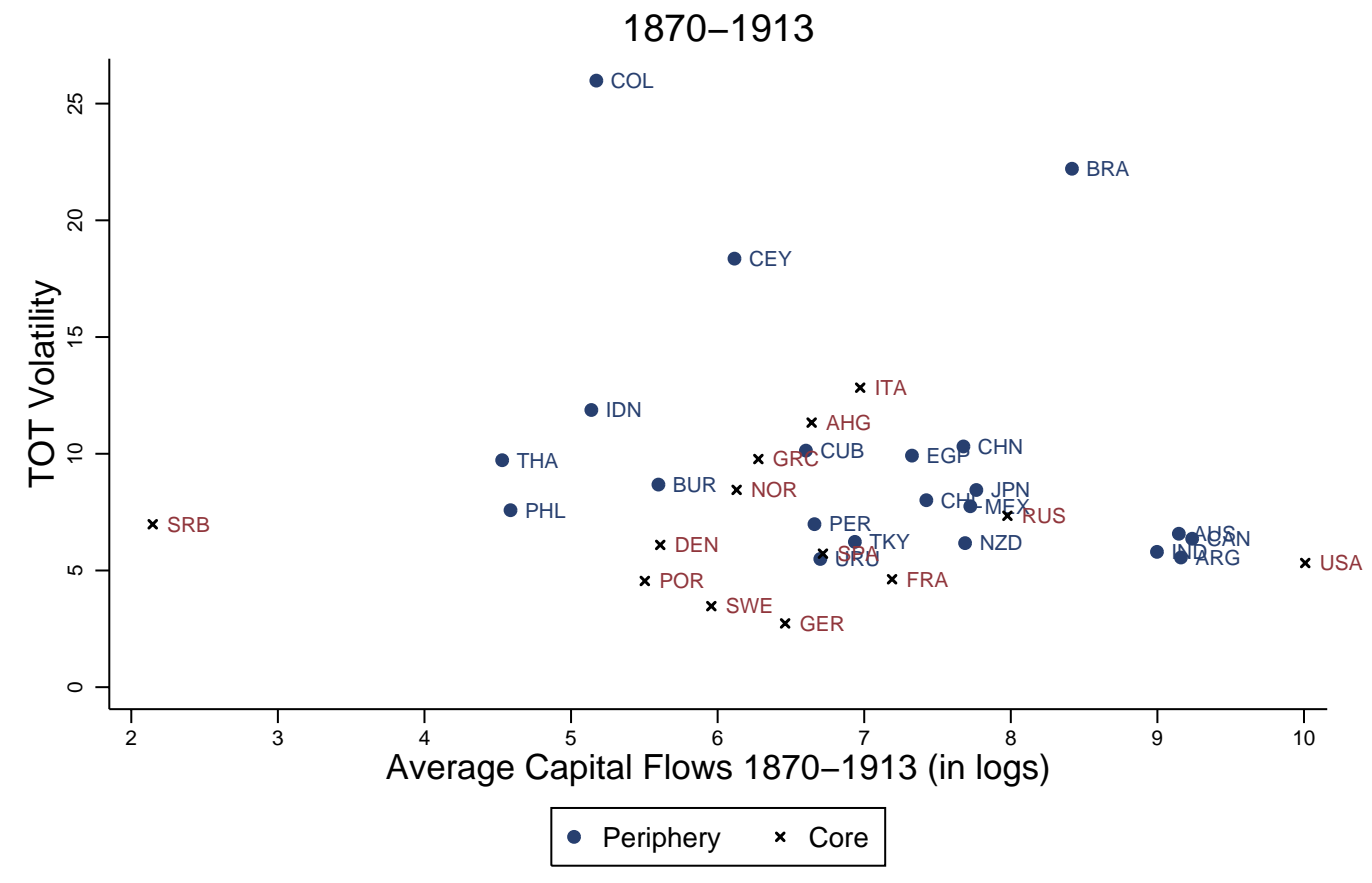


Table 1: Profile of the Core and Periphery

\begin{tabular}{|c|c|c|c|c|c|c|c|c|c|c|c|c|}
\hline & \multicolumn{4}{|c|}{$1870-1889$} & \multicolumn{4}{|c|}{$1890-1909$} & \multicolumn{4}{|c|}{$1920-1939$} \\
\hline & $\begin{array}{l}\text { GDP per } \\
\text { capita }\end{array}$ & $\begin{array}{l}\text { Primary } \\
\text { Products } \\
\text { as a \% of } \\
\text { Exports }\end{array}$ & $\begin{array}{c}\text { Top } 2 \\
\text { Exports as } \\
\text { a \% of Top } \\
5 \text { Exports }\end{array}$ & $\begin{array}{l}\text { Exports as } \\
\mathrm{a} \% \text { of GDP }\end{array}$ & $\begin{array}{l}\text { GDP per } \\
\text { capita }\end{array}$ & $\begin{array}{l}\text { Primary } \\
\text { Products } \\
\text { as a \% of } \\
\text { Exports }\end{array}$ & $\begin{array}{c}\text { Top } 2 \\
\text { Exports as } \\
\text { a \% of Top } \\
5 \text { Exports }\end{array}$ & $\begin{array}{l}\text { Exports as } \\
\mathrm{a} \% \text { of GDP }\end{array}$ & $\begin{array}{l}\text { GDP per } \\
\text { capita }\end{array}$ & $\begin{array}{l}\text { Primary } \\
\text { Products } \\
\text { as } \% \text { of } \\
\text { Exports }\end{array}$ & $\begin{array}{c}\text { Top } 2 \\
\text { Exports as } \\
\text { a \% of Top } \\
5 \text { Exports }\end{array}$ & $\begin{array}{l}\text { Exports as } \\
\mathrm{a} \% \text { of GDP }\end{array}$ \\
\hline \multicolumn{13}{|l|}{ PERIPHERY } \\
\hline \multicolumn{13}{|c|}{ European "Frontier" Offshoots } \\
\hline Australia & 4,442 & $97 \%$ & $98 \%$ & $15 \%$ & 4,394 & $97 \%$ & $84 \%$ & $20 \%$ & 5,268 & $96 \%$ & $76 \%$ & $15 \%$ \\
\hline Canada & 1,822 & $95 \%$ & $96 \%$ & $12 \%$ & 2,801 & $91 \%$ & $68 \%$ & $15 \%$ & 3,993 & $74 \%$ & $51 \%$ & $19 \%$ \\
\hline \multirow[t]{2}{*}{ New Zealand } & 3,668 & $99 \%$ & $100 \%$ & $16 \%$ & 4,295 & $96 \%$ & $89 \%$ & $23 \%$ & 5,232 & $99 \%$ & $69 \%$ & $25 \%$ \\
\hline & 3,311 & $97 \%$ & $98 \%$ & $15 \%$ & 3,830 & $95 \%$ & $81 \%$ & $19 \%$ & 4,831 & $89 \%$ & $65 \%$ & $20 \%$ \\
\hline \multicolumn{13}{|l|}{ Latin America } \\
\hline Argentina & 1,676 & $100 \%$ & $87 \%$ & $15 \%$ & 2,823 & $99 \%$ & $58 \%$ & $19 \%$ & 3,912 & $99 \%$ & $47 \%$ & $14 \%$ \\
\hline Brazil & 755 & $100 \%$ & $86 \%$ & $17 \%$ & 749 & $100 \%$ & $91 \%$ & $21 \%$ & 1,087 & $100 \%$ & $92 \%$ & $9 \%$ \\
\hline Chile & 1,185 & $99 \%$ & $100 \%$ & $22 \%$ & 1,923 & $99 \%$ & $100 \%$ & $19 \%$ & 2,800 & $100 \%$ & $100 \%$ & $12 \%$ \\
\hline Colombia & 1,113 & $99 \%$ & $100 \%$ & $4 \%$ & 1,034 & $99 \%$ & $100 \%$ & $6 \%$ & 1,486 & $99 \%$ & $100 \%$ & $7 \%$ \\
\hline Cuba & 1,647 & $80 \%$ & $a$ & $49 \%$ & 1,825 & $83 \%$ & $100 \%$ & $41 \%$ & 1,440 & $96 \%$ & $100 \%$ & $41 \%$ \\
\hline Mexico & 835 & $100 \%$ & $99 \%$ & $4 \%$ & 1,183 & $100 \%$ & $86 \%$ & $5 \%$ & 1,463 & $99 \%$ & $62 \%$ & $7 \%$ \\
\hline Peru & 497 & $99 \%$ & $74 \%$ & $24 \%$ & 802 & $99 \%$ & $55 \%$ & $10 \%$ & 1,451 & $100 \%$ & $67 \%$ & $12 \%$ \\
\hline \multirow[t]{2}{*}{ Uruguay } & 1,676 & $100 \%$ & $74 \%$ & $22 \%$ & 2,823 & $100 \%$ & $72 \%$ & $19 \%$ & 3,912 & $100 \%$ & $85 \%$ & $18 \%$ \\
\hline & 1,173 & $97 \%$ & $89 \%$ & $20 \%$ & 1,645 & $97 \%$ & $83 \%$ & $17 \%$ & 2,194 & $99 \%$ & $82 \%$ & $15 \%$ \\
\hline \multicolumn{13}{|l|}{ Asia \& the Middle East } \\
\hline Burma (Myanmar) & 628 & $91 \%$ & $100 \%$ & $14 \%$ & 622 & $86 \%$ & $93 \%$ & $12 \%$ & 751 & $98 \%$ & $83 \%$ & $45 \%$ \\
\hline Ceylon (Sri Lanka) & 730 & $98 \%$ & $100 \%$ & $11 \%$ & 932 & $98 \%$ & $100 \%$ & $13 \%$ & 1,114 & $98 \%$ & $100 \%$ & $15 \%$ \\
\hline China & 565 & $98 \%$ & $73 \%$ & $1 \%$ & 648 & $93 \%$ & $66 \%$ & $1 \%$ & 769 & $85 \%$ & $43 \%$ & $1 \%$ \\
\hline Egypt & 369 & $93 \%$ & $100 \%$ & $29 \%$ & 487 & $96 \%$ & $100 \%$ & $25 \%$ & 650 & $97 \%$ & $100 \%$ & $18 \%$ \\
\hline India & 660 & $98 \%$ & $55 \%$ & $4 \%$ & 723 & $96 \%$ & $51 \%$ & $5 \%$ & 1,083 & $97 \%$ & $59 \%$ & $6 \%$ \\
\hline Indonesia & 581 & $91 \%$ & . & $3 \%$ & 629 & $86 \%$ & $60 \%$ & $4 \%$ & 651 & $75 \%$ & $54 \%$ & $4 \%$ \\
\hline Japan & 800 & $71 \%$ & $100 \%$ & $1 \%$ & 1,108 & $70 \%$ & $99 \%$ & $4 \%$ & 1,948 & $44 \%$ & $89 \%$ & $7 \%$ \\
\hline Philippines & 955 & $96 \%$ & $81 \%$ & $5 \%$ & 1,086 & $95 \%$ & $90 \%$ & $4 \%$ & 1,527 & $91 \%$ & $81 \%$ & $5 \%$ \\
\hline Siam (Thailand) & 751 & $99 \%$ & $100 \%$ & $2 \%$ & 811 & $99 \%$ & $100 \%$ & $6 \%$ & 815 & $98 \%$ & $87 \%$ & $7 \%$ \\
\hline \multirow{2}{*}{ Turkey } & 831 & $99 \%$ & $50 \%$ & $6 \%$ & 941 & $97 \%$ & $59 \%$ & $9 \%$ & 936 & $92 \%$ & $72 \%$ & $5 \%$ \\
\hline & 834 & $92 \%$ & $83 \%$ & $4 \%$ & 987 & $90 \%$ & $87 \%$ & $6 \%$ & 1,307 & $81 \%$ & $82 \%$ & $6 \%$ \\
\hline \multicolumn{13}{|l|}{ CORE } \\
\hline \multicolumn{13}{|l|}{$\overline{\text { Industrial Leaders }}$} \\
\hline France & 2,119 & $43 \%$ & $b$ & $13 \%$ & 2,739 & $40 \%$ & $b$ & $15 \%$ & 4,100 & $35 \%$ & $b$ & $10 \%$ \\
\hline Germany & 2,184 & $38 \%$ & $b$ & $9 \%$ & 3,007 & $33 \%$ & $b$ & $9 \%$ & 4,001 & $24 \%$ & $b$ & $11 \%$ \\
\hline United Kingdom & 3,598 & $12 \%$ & $b$ & $14 \%$ & 4,419 & $17 \%$ & $b$ & $14 \%$ & 5,112 & $22 \%$ & $b$ & $12 \%$ \\
\hline \multirow[t]{2}{*}{ United States } & 2,952 & $86 \%$ & $b$ & $6 \%$ & 4,126 & $80 \%$ & $b$ & $6 \%$ & 5,969 & $57 \%$ & $b$ & $5 \%$ \\
\hline & 2,713 & $45 \%$ & . & $10 \%$ & 3,573 & $43 \%$ & . & $11 \%$ & 4,795 & $35 \%$ & . & $9 \%$ \\
\hline \multicolumn{13}{|c|}{ European Industrial Latecomers } \\
\hline Austria/Austria-Hungary & 1,108 & $35 \%$ & $b$ & $9 \%$ & 1,545 & $41 \%$ & $b$ & $9 \%$ & 3,211 & $35 \%$ & $b$ & $10 \%$ \\
\hline Denmark & 2,105 & $96 \%$ & a & $14 \%$ & 2,913 & $96 \%$ & $88 \%$ & $22 \%$ & 4,791 & $90 \%$ & $91 \%$ & $20 \%$ \\
\hline Italy & 1,516 & $87 \%$ & $b$ & $6 \%$ & 1,784 & $74 \%$ & $b$ & $7 \%$ & 2,888 & $48 \%$ & $b$ & $5 \%$ \\
\hline Norway & 1,446 & $90 \%$ & $100 \%$ & $13 \%$ & 1,763 & $74 \%$ & $94 \%$ & $18 \%$ & 3,126 & $64 \%$ & $100 \%$ & $20 \%$ \\
\hline \multirow[t]{2}{*}{ Sweden } & 1,875 & $85 \%$ & $b$ & $9 \%$ & 2,483 & $75 \%$ & $b$ & $12 \%$ & 3,722 & $58 \%$ & $b$ & $15 \%$ \\
\hline & 1,610 & $79 \%$ & 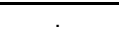 & $10 \%$ & 2,098 & $72 \%$ & & $13 \%$ & 3,548 & $59 \%$ & . & $14 \%$ \\
\hline \multicolumn{13}{|l|}{ European Periphery } \\
\hline Greece & 1,343 & $94 \%$ & $a$ & $7 \%$ & 1,487 & $90 \%$ & $73 \%$ & $7 \%$ & 2,321 & $96 \%$ & $86 \%$ & $4 \%$ \\
\hline Portugal & 1,151 & $96 \%$ & $75 \%$ & $6 \%$ & 1,348 & $92 \%$ & $73 \%$ & $7 \%$ & 1,562 & $75 \%$ & $85 \%$ & $7 \%$ \\
\hline Russia/USSR & 976 & $97 \%$ & $79 \%$ & $4 \%$ & 1,178 & $96 \%$ & $73 \%$ & $4 \%$ & 1,593 & $85 \%$ & $48 \%$ & $1 \%$ \\
\hline Serbia/Yugoslavia & 852 & $96 \%$ & $73 \%$ & $6 \%$ & 944 & $96 \%$ & $77 \%$ & $7 \%$ & 1,225 & $92 \%$ & $64 \%$ & $5 \%$ \\
\hline Spain & 1,588 & $73 \%$ & $64 \%$ & $5 \%$ & 2,009 & $75 \%$ & $46 \%$ & $7 \%$ & 2,557 & $80 \%$ & $a$ & $4 \%$ \\
\hline & 1,182 & $91 \%$ & $73 \%$ & $5 \%$ & 1,393 & $90 \%$ & $69 \%$ & $6 \%$ & 1,852 & $86 \%$ & $71 \%$ & $4 \%$ \\
\hline
\end{tabular}

Sources: See data appendix.

Note a: No data available for this period.

Note b: Existing terms of trade series, for which an export breakdown was not available, were used for the Industrial Leaders and several of the European Latecomers. 
Table 2: GDP Growth and the Terms of Trade, 1870-1939

Dependent Variable: Decadal average GDP per capita growth

TOT Growth Measure: Decadal growth in a Hodrick-Prescott filtered trend

TOT Volatility Measure: Decadal standard deviation of annual departures from trend

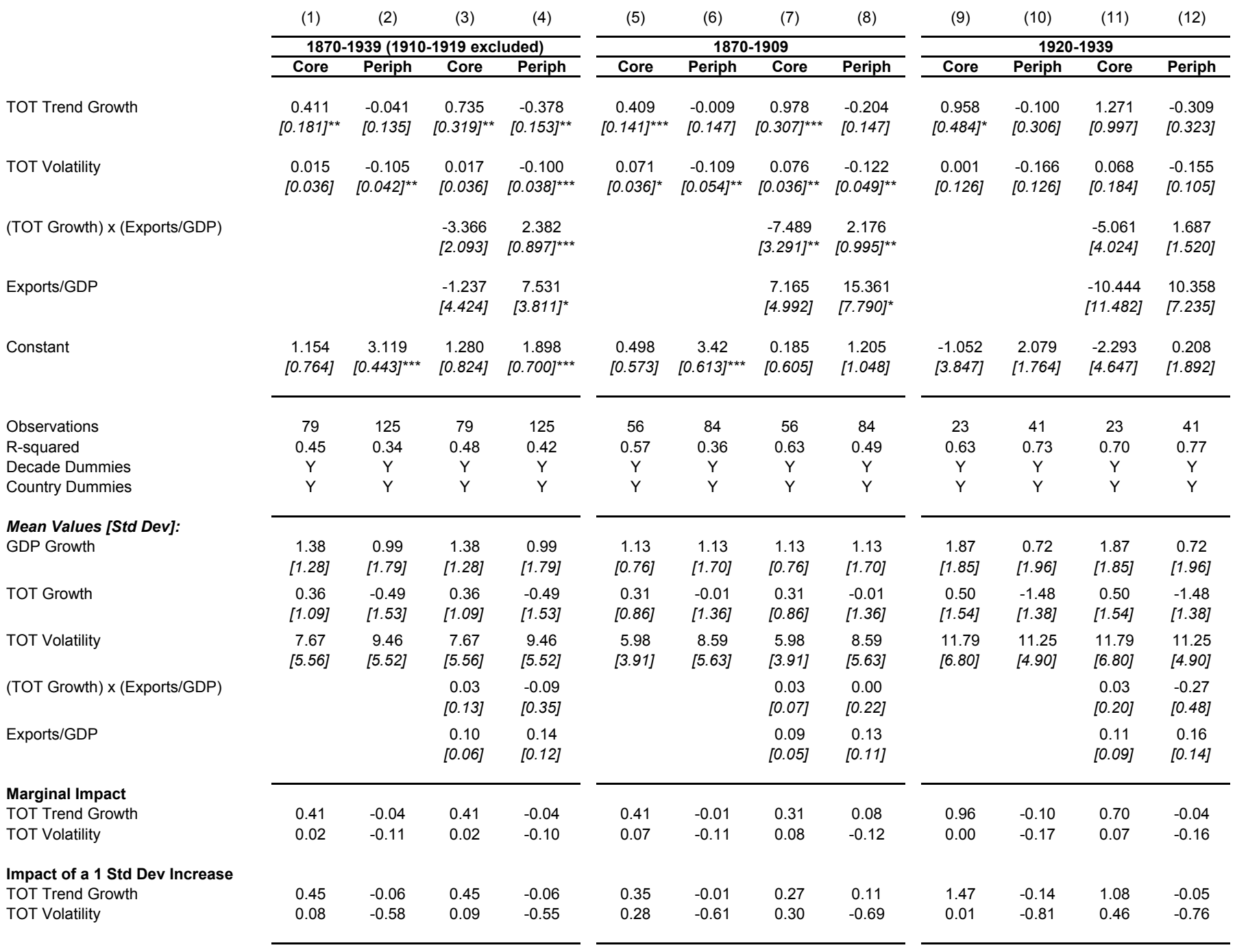

Robust standard errors in brackets

* significant at 10\%; ** significant at $5 \%$; *** significant at $1 \%$ 
Table 3: British Capital Flows and the Terms of Trade, 1870-1909

Dependent Variable: Natural log of average decadal capital inflows from Britain

TOT Growth Measure: Decadal growth in a Hodrick-Prescott filtered trend

TOT Volatility Measure: Decadal standard deviation of annual departures from trend

Dependent Variable:

\begin{tabular}{cccc}
$(1)$ & $(2)$ & $(3)$ & $(4)$ \\
\hline \multicolumn{4}{c}{$\ln ($ Capital Flows) } \\
\hline \multicolumn{4}{c}{$1870-1909$} \\
\hline Core & Periph & Core & Periph \\
\hline
\end{tabular}

TOT Growth

$\begin{array}{cccc}0.036 & 0.03 & 1.212 & 0.004 \\ {[0.372]} & {[0.092]} & {[0.872]} & {[0.152]}\end{array}$

TOT Volatility

$\begin{array}{cccc}-0.039 & -0.044 & -0.031 & -0.045 \\ {[0.116]} & {[0.024]^{*}} & {[0.124]} & {[0.025]^{*}}\end{array}$

(TOT Growth) x (Exports/GDP)

$-16.977 \quad 0.208$

[10.847] [0.952]

Exports/GDP

$20.273 \quad-0.041$

Constant

$[22.264] \quad[3.850]$

Observations

R-squared

Decade Dummies

Country Dummies

Mean Values [Std Dev]

In(Capital Flows)

TOT Growth

TOT Volatility

(TOT Growth) x (Exports/GDP)

$\begin{array}{llll}6.576 & 8.236 & 4.461 & 8.252 \\ 0.72]^{* * *} & {[0.429]^{* * *}} & {[2.246]^{*}} & {[0.647]^{* *}}\end{array}$

$[0.722]^{\star * \star}[0.429]^{\star \star *}[2.246]^{*}[0.647]^{\star \star \star}$

\begin{tabular}{cccc}
52 & 84 & 52 & 84 \\
0.69 & 0.78 & 0.72 & 0.79 \\
$Y$ & $Y$ & $Y$ & $Y$ \\
$Y$ & $Y$ & $Y$ & $Y$ \\
& & & \\
\hline & & & \\
5.80 & 6.42 & 5.80 & 6.42 \\
{$[2.40]$} & {$[2.20]$} & {$[2.40]$} & {$[2.20]$} \\
0.32 & -0.01 & 0.32 & -0.01 \\
{$[0.87]$} & {$[1.36]$} & {$[0.87]$} & {$[1.36]$} \\
& & & \\
6.23 & 8.59 & 6.23 & 8.59 \\
{$[3.93]$} & {$[5.63]$} & {$[3.93]$} & {$[5.63]$} \\
& & & \\
0.03 & 0.00 & 0.03 & 0.00 \\
{$[0.87]$} & {$[0.22]$} & {$[0.87]$} & {$[0.22]$} \\
& & & \\
0.09 & 0.13 & 0.09 & 0.13 \\
{$[0.04]$} & {$[0.11]$} & {$[0.04]$} & {$[0.11]$} \\
& & & \\
\hline & & & \\
0.04 & 0.03 & -0.23 & 0.03 \\
-0.04 & -0.04 & -0.03 & -0.05 \\
& & & \\
0.03 & 0.04 & -0.20 & 0.04 \\
-0.15 & -0.25 & -0.12 & -0.25 \\
\hline
\end{tabular}

Exports/GDP

Marginal Impact

TOT Growth

TOT Volatility

Impact of a 1 Std Dev Increase

TOT Growth

Robust standard errors in brackets

* significant at 10\%; ** significant at 5\%; *** significant at 1\% 


\section{Table A1: GDP Growth and the Terms of Trade With an Alternative Measure of Terms of Trade Growth Volatility, 1870-1939}

Dependent Variable: Decadal average GDP per capita growth

TOT Growth Measure: Decadal average growth rate of the TOT index

TOT Volatility Measure: Standard Deviation of the growth rate of the TOT index

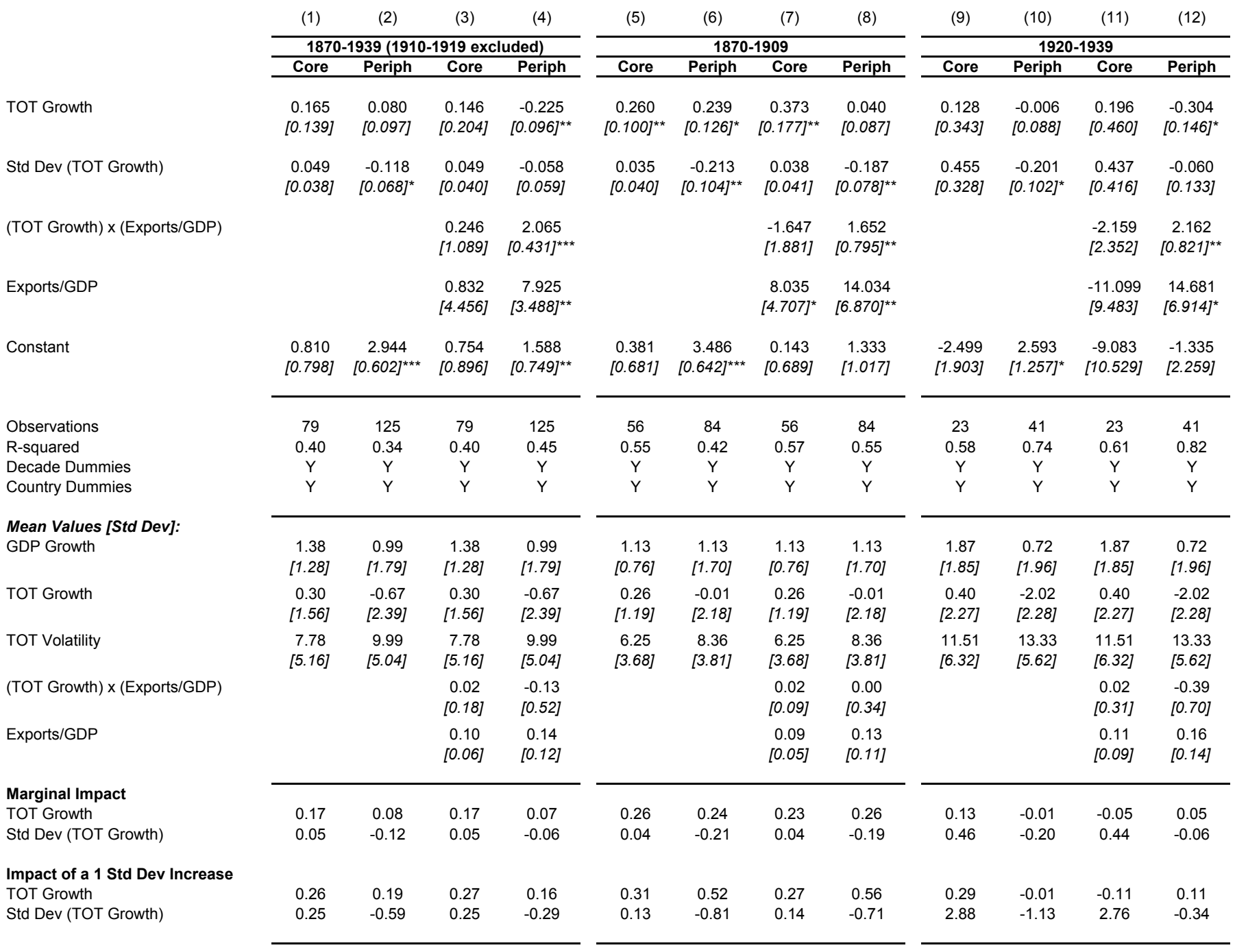

Robust standard errors in brackets

* significant at 10\%; ** significant at 5\%; *** significant at $1 \%$ 
Table A2: Table 2 Using Alternative Filters, 1870-1939

Dependent Variable: Decadal average GDP per capita growth

TOT Growth Measure: Decadal growth in a filtered trend (alternative trends examined below)

TOT Volatility Measure: Decadal standard deviation of annual departures from trend

\begin{tabular}{|c|c|c|c|c|c|c|c|c|c|c|c|c|}
\hline & (1) & $(2)$ & (3) & $(4)$ & $(5)$ & (6) & $(7)$ & (8) & (9) & $(10)$ & $(11)$ & $(12)$ \\
\hline & \multicolumn{4}{|c|}{ HP Filter $(\lambda=300)$ from Table 2} & \multicolumn{4}{|c|}{ HP Filter $(\lambda=100)$} & \multicolumn{4}{|c|}{ MA Filter (7 periods) } \\
\hline & Core & Periph & Core & Periph & Core & Periph & Core & Periph & Core & Periph & Core & Periph \\
\hline TOT Growth & $\begin{array}{c}0.411 \\
{[0.181]^{\star *}}\end{array}$ & $\begin{array}{c}-0.041 \\
{[0.135]}\end{array}$ & $\begin{array}{c}0.735 \\
{[0.319]^{* *}}\end{array}$ & $\begin{array}{c}-0.378 \\
{[0.153]^{\star *}}\end{array}$ & $\begin{array}{c}0.377 \\
{[0.160]^{* *}}\end{array}$ & $\begin{array}{c}-0.017 \\
{[0.116]}\end{array}$ & $\begin{array}{c}0.596 \\
{[0.274]^{* *}}\end{array}$ & $\begin{array}{c}-0.33 \\
{[0.121]^{\star \star *}}\end{array}$ & $\begin{array}{c}0.350 \\
{[0.146]^{\star *}}\end{array}$ & $\begin{array}{c}-0.025 \\
{[0.104]}\end{array}$ & $\begin{array}{c}0.544 \\
{[0.254]^{\star *}}\end{array}$ & $\begin{array}{c}-0.308 \\
{[0.112]^{\star * *}}\end{array}$ \\
\hline TOT Volatility & $\begin{array}{c}0.015 \\
{[0.036]}\end{array}$ & $\begin{array}{c}-0.105 \\
{[0.042]^{* *}}\end{array}$ & $\begin{array}{c}0.017 \\
{[0.036]}\end{array}$ & $\begin{array}{c}-0.100 \\
{[0.038]^{* * *}}\end{array}$ & $\begin{array}{c}0.022 \\
{[0.039]}\end{array}$ & $\begin{array}{c}-0.113 \\
{[0.048]^{* *}}\end{array}$ & $\begin{array}{c}0.02 \\
{[0.041]}\end{array}$ & $\begin{array}{c}-0.103 \\
{[0.043]^{* *}}\end{array}$ & $\begin{array}{c}0.027 \\
{[0.035]}\end{array}$ & $\begin{array}{c}-0.122 \\
{[0.067]^{*}}\end{array}$ & $\begin{array}{c}0.021 \\
{[0.037]}\end{array}$ & $\begin{array}{c}-0.100 \\
{[0.061]}\end{array}$ \\
\hline (TOT Growth) x (Exports/GDP) & & & $\begin{array}{c}-3.366 \\
{[2.093]}\end{array}$ & $\begin{array}{c}2.382 \\
{[0.897]^{\star * *}}\end{array}$ & & & $\begin{array}{c}-2.21 \\
{[1.782]}\end{array}$ & $\begin{array}{c}2.165 \\
{[0.707]^{\star \star *}}\end{array}$ & & & $\begin{array}{l}-1.853 \\
{[1.632]}\end{array}$ & $\begin{array}{c}2.011 \\
{[0.634]^{\star * *}}\end{array}$ \\
\hline Exports/GDP & & & $\begin{array}{l}-1.237 \\
{[4.424]}\end{array}$ & $\begin{array}{c}7.531 \\
{[3.811]^{*}}\end{array}$ & & & $\begin{array}{c}-0.466 \\
{[4.847]}\end{array}$ & $\begin{array}{c}7.714 \\
{[3.896]^{*}}\end{array}$ & & & $\begin{array}{c}-0.06 \\
{[5.053]}\end{array}$ & $\begin{array}{c}7.409 \\
{[3.752]^{*}}\end{array}$ \\
\hline Constant & $\begin{array}{c}1.154 \\
{[0.764]}\end{array}$ & $\begin{array}{c}3.119 \\
{[0.443]^{\star \star *}}\end{array}$ & $\begin{array}{c}1.28 \\
{[0.824]}\end{array}$ & $\begin{array}{c}1.898 \\
{[0.700]^{\star * *}}\end{array}$ & $\begin{array}{c}1.096 \\
{[0.764]}\end{array}$ & $\begin{array}{c}3.127 \\
{[0.451]^{\star * *}}\end{array}$ & $\begin{array}{c}1.2 \\
{[0.857]}\end{array}$ & $\begin{array}{c}1.862 \\
{[0.719]^{\star *}}\end{array}$ & $\begin{array}{c}1.106 \\
{[0.735]}\end{array}$ & $\begin{array}{c}3.017 \\
{[0.588]^{\star \star *}}\end{array}$ & $\begin{array}{c}1.227 \\
{[0.833]}\end{array}$ & $\begin{array}{c}1.956 \\
{[0.730]^{* \star *}}\end{array}$ \\
\hline Observations & 79 & 125 & 79 & 125 & 79 & 125 & 79 & 125 & 79 & 125 & 79 & 125 \\
\hline R-squared & 0.45 & 0.34 & 0.48 & 0.42 & 0.46 & 0.34 & 0.49 & 0.43 & 0.46 & 0.33 & 0.48 & 0.42 \\
\hline Decade Dummies & $\mathrm{Y}$ & $\mathrm{Y}$ & $\mathrm{Y}$ & $\mathrm{Y}$ & $\mathrm{Y}$ & $\mathrm{Y}$ & $\mathrm{Y}$ & $\mathrm{Y}$ & $\mathrm{Y}$ & $\mathrm{Y}$ & $\mathrm{Y}$ & $\mathrm{Y}$ \\
\hline Country Dummies & $\mathrm{Y}$ & $\mathrm{Y}$ & Y & $\mathrm{Y}$ & $\mathrm{Y}$ & Y & $\mathrm{Y}$ & $\mathrm{Y}$ & Y & $\mathrm{Y}$ & $\mathrm{Y}$ & $\mathrm{Y}$ \\
\hline
\end{tabular}

Robust standard errors in brackets

* significant at 10\%; ** significant at $5 \%$; ${ }^{* * *}$ significant at $1 \%$ 


\section{Table A3: Table 2 with European Offshoots Excluded from the Periphery}

Dependent Variable: Decadal average GDP per capita growth

TOT Growth Measure: Decadal growth in a Hodrick-Prescott filtered trend

TOT Volatility Measure: Decadal standard deviation of annual departures from trend

\begin{tabular}{|c|c|c|c|c|c|c|c|c|c|c|c|c|}
\hline & (1) & (2) & (3) & (4) & (5) & (6) & (7) & (8) & (9) & (10) & $(11)$ & $(12)$ \\
\hline & \multicolumn{4}{|c|}{ 1870-1939 (1910-1919 excluded) } & \multicolumn{4}{|c|}{$1870-1909$} & \multicolumn{4}{|c|}{$1920-1939$} \\
\hline & Core & Periph & Core & Periph & Core & Periph & Core & Periph & Core & Periph & Core & Periph \\
\hline TOT Trend Growth & $\begin{array}{c}0.421 \\
{[0.143]^{\star * *}}\end{array}$ & $\begin{array}{l}-0.032 \\
{[0.153]}\end{array}$ & $\begin{array}{c}0.716 \\
{[0.296]^{\star *}}\end{array}$ & $\begin{array}{c}-0.367 \\
{[0.158]^{* *}}\end{array}$ & $\begin{array}{c}0.383 \\
{[0.117]^{\star * *}}\end{array}$ & $\begin{array}{c}0.099 \\
{[0.164]}\end{array}$ & $\begin{array}{c}0.478 \\
{[0.256]^{*}}\end{array}$ & $\begin{array}{l}-0.216 \\
{[0.161]}\end{array}$ & $\begin{array}{c}0.535 \\
{[0.513]}\end{array}$ & $\begin{array}{c}0.085 \\
{[0.289]}\end{array}$ & $\begin{array}{c}1.417 \\
{[0.798]}\end{array}$ & $\begin{array}{l}-0.226 \\
{[0.341]}\end{array}$ \\
\hline TOT Volatility & $\begin{array}{c}0.007 \\
{[0.034]}\end{array}$ & $\begin{array}{c}-0.112 \\
{[0.050]^{\star \star}}\end{array}$ & $\begin{array}{c}0.005 \\
{[0.035]}\end{array}$ & $\begin{array}{c}-0.11 \\
{[0.045]^{* *}}\end{array}$ & $\begin{array}{c}0.047 \\
{[0.035]}\end{array}$ & $\begin{array}{c}-0.113 \\
{[0.047]^{* *}}\end{array}$ & $\begin{array}{c}0.052 \\
{[0.036]}\end{array}$ & $\begin{array}{c}-0.131 \\
{[0.054]^{\star *}}\end{array}$ & $\begin{array}{c}0.026 \\
{[0.111]}\end{array}$ & $\begin{array}{l}-0.195 \\
{[0.133]}\end{array}$ & $\begin{array}{c}0.053 \\
{[0.159]}\end{array}$ & $\begin{array}{c}-0.151 \\
{[0.124]}\end{array}$ \\
\hline (TOT Growth) x (Exports/GDP) & & & $\begin{array}{c}-1.988 \\
{[1.800]}\end{array}$ & $\begin{array}{c}2.408 \\
{[0.841]^{\star \star \star}}\end{array}$ & & & $\begin{array}{l}-1.326 \\
{[2.025]}\end{array}$ & $\begin{array}{c}2.23 \\
{[1.211]^{\star}}\end{array}$ & & & $\begin{array}{c}-7.826 \\
{[3.723]^{*}}\end{array}$ & $\begin{array}{c}1.814 \\
{[1.653]}\end{array}$ \\
\hline Exports/GDP & & & $\begin{array}{c}3.681 \\
{[3.643]}\end{array}$ & $\begin{array}{c}6.374 \\
{[4.288]}\end{array}$ & & & $\begin{array}{c}14.437 \\
{[6.263]^{\star *}}\end{array}$ & $\begin{array}{r}15.354 \\
{[9.512]}\end{array}$ & & & $\begin{array}{l}-7.807 \\
{[7.039]}\end{array}$ & $\begin{array}{c}11.591 \\
{[7.507]}\end{array}$ \\
\hline Constant & $\begin{array}{c}3.279 \\
{[0.646]^{\star * *}}\end{array}$ & $\begin{array}{c}2.337 \\
{[1.331]^{\star}}\end{array}$ & $\begin{array}{c}2.559 \\
{[1.003]^{\star *}}\end{array}$ & $\begin{array}{c}1.994 \\
{[1.389]}\end{array}$ & $\begin{array}{c}1.449 \\
{[0.395]^{\star * *}}\end{array}$ & $\begin{array}{c}3.727 \\
{[1.303]^{\star * *}}\end{array}$ & $\begin{array}{l}-0.395 \\
{[0.859]}\end{array}$ & $\begin{array}{c}1.403 \\
{[1.089]}\end{array}$ & $\begin{array}{c}0.793 \\
{[2.010]}\end{array}$ & $\begin{array}{c}2.236 \\
{[2.023]}\end{array}$ & $\begin{array}{c}0.847 \\
{[1.961]}\end{array}$ & $\begin{array}{c}-0.568 \\
{[2.033]}\end{array}$ \\
\hline Observations & 109 & 95 & 109 & 95 & 76 & 126 & 76 & 64 & 33 & 31 & 33 & 31 \\
\hline R-squared & 0.39 & 0.30 & 0.42 & 0.39 & 0.55 & 0.23 & 0.62 & 0.43 & 0.51 & 0.79 & 0.66 & 0.82 \\
\hline Decade Dummies & Y & $\mathrm{Y}$ & Y & $\mathrm{Y}$ & $\mathrm{Y}$ & Y & Y & Y & Y & Y & Y & $\mathrm{Y}$ \\
\hline Country Dummies & $\mathrm{Y}$ & $\mathrm{Y}$ & $\mathrm{Y}$ & $\mathrm{Y}$ & $\mathrm{Y}$ & Y & Y & $\mathrm{Y}$ & $\mathrm{Y}$ & Y & $\mathrm{Y}$ & $\mathrm{Y}$ \\
\hline
\end{tabular}

Robust standard errors in brackets

* significant at 10\%; ** significant at $5 \%$; ${ }^{* * *}$ significant at $1 \%$ 


\section{Table A4: Table 2 with European Periphery Included in the Periphery}

Dependent Variable: Decadal average GDP per capita growth

TOT Growth Measure: Decadal growth in a Hodrick-Prescott filtered trend

TOT Volatility Measure: Decadal standard deviation of annual departures from trend

\begin{tabular}{|c|c|c|c|c|c|c|c|c|c|c|c|c|}
\hline & (1) & (2) & (3) & (4) & (5) & (6) & (7) & (8) & (9) & $(10)$ & (11) & $(12)$ \\
\hline & \multicolumn{4}{|c|}{$1870-1939$ (1910-1919 excluded) } & \multicolumn{4}{|c|}{$1870-1909$} & \multicolumn{4}{|c|}{$1920-1939$} \\
\hline & Core & Periph & Core & Periph & Core & Periph & Core & Periph & Core & Periph & Core & Periph \\
\hline TOT Trend Growth & $\begin{array}{c}0.133 \\
{[0.139]}\end{array}$ & $\begin{array}{c}0.135 \\
{[0.131]}\end{array}$ & $\begin{array}{c}0.305 \\
{[0.371]}\end{array}$ & $\begin{array}{c}-0.098 \\
{[0.169]}\end{array}$ & $\begin{array}{c}0.273 \\
{[0.188]}\end{array}$ & $\begin{array}{c}0.158 \\
{[0.134]}\end{array}$ & $\begin{array}{c}1.091 \\
{[0.690]}\end{array}$ & $\begin{array}{c}-0.136 \\
{[0.134]}\end{array}$ & $\begin{array}{c}0.392 \\
{[0.457]}\end{array}$ & $\begin{array}{c}0.269 \\
{[0.329]}\end{array}$ & $\begin{array}{c}0.207 \\
{[1.358]}\end{array}$ & $\begin{array}{c}0.446 \\
{[0.549]}\end{array}$ \\
\hline TOT Volatility & $\begin{array}{c}0.064 \\
{[0.047]}\end{array}$ & $\begin{array}{c}-0.048 \\
{[0.033]}\end{array}$ & $\begin{array}{c}0.071 \\
{[0.049]}\end{array}$ & $\begin{array}{c}-0.042 \\
{[0.032]}\end{array}$ & $\begin{array}{c}0.046 \\
{[0.036]}\end{array}$ & $\begin{array}{c}-0.054 \\
{[0.031]^{*}}\end{array}$ & $\begin{array}{c}0.051 \\
{[0.036]}\end{array}$ & $\begin{array}{c}-0.11 \\
{[0.044]^{\star *}}\end{array}$ & $\begin{array}{c}0.149 \\
{[0.230]}\end{array}$ & $\begin{array}{l}-0.139 \\
{[0.087]}\end{array}$ & $\begin{array}{c}0.302 \\
{[0.188]}\end{array}$ & $\begin{array}{c}-0.188 \\
{[0.107]^{*}}\end{array}$ \\
\hline (TOT Growth) x (Exports/GDP) & & & $\begin{array}{c}-1.317 \\
{[2.394]}\end{array}$ & $\begin{array}{c}1.842 \\
{[1.034]^{\star}}\end{array}$ & & & $\begin{array}{c}-8.754 \\
{[6.169]}\end{array}$ & $\begin{array}{c}2.007 \\
{[0.938]^{\star *}}\end{array}$ & & & $\begin{array}{l}-2.373 \\
{[4.642]}\end{array}$ & $\begin{array}{c}-0.042 \\
{[2.042]}\end{array}$ \\
\hline Exports/GDP & & & $\begin{array}{c}-0.558 \\
{[5.096]}\end{array}$ & $\begin{array}{c}5.941 \\
{[3.980]}\end{array}$ & & & $\begin{array}{c}13.043 \\
{[5.763]^{* *}}\end{array}$ & $\begin{array}{c}15.605 \\
{[7.874]^{*}}\end{array}$ & & & $\begin{array}{c}-17.021 \\
{[11.297]}\end{array}$ & $\begin{array}{c}7.675 \\
{[7.433]}\end{array}$ \\
\hline Constant & $\begin{array}{c}1.735 \\
{[0.923]^{*}}\end{array}$ & $\begin{array}{c}2.404 \\
{[0.496]^{\star * *}}\end{array}$ & $\begin{array}{c}1.641 \\
{[1.007]}\end{array}$ & $\begin{array}{c}1.579 \\
{[0.715]^{* *}}\end{array}$ & $\begin{array}{c}1.476 \\
{[0.245]^{\star * *}}\end{array}$ & $\begin{array}{c}1.188 \\
{[0.692]^{*}}\end{array}$ & $\begin{array}{c}0.164 \\
{[0.527]}\end{array}$ & $\begin{array}{c}0.963 \\
{[1.045]}\end{array}$ & $\begin{array}{c}0.422 \\
{[3.291]}\end{array}$ & $\begin{array}{c}2.317 \\
{[1.671]}\end{array}$ & $\begin{array}{c}1.655 \\
{[3.730]}\end{array}$ & $\begin{array}{c}1.602 \\
{[2.124]}\end{array}$ \\
\hline Observations & 50 & 154 & 50 & 154 & 36 & 201 & 36 & 104 & 14 & 50 & 14 & 50 \\
\hline R-squared & 0.48 & 0.26 & 0.49 & 0.31 & 0.41 & 0.19 & 0.51 & 0.46 & 0.74 & 0.62 & 0.90 & 0.64 \\
\hline Decade Dummies & Y & Y & Y & Y & Y & $Y$ & Y & Y & Y & $Y$ & $Y$ & Y \\
\hline Country Dummies & $\mathrm{Y}$ & $\mathrm{Y}$ & $Y$ & $\mathrm{Y}$ & Y & Y & Y & $\mathrm{Y}$ & $\mathrm{Y}$ & Y & $Y$ & Y \\
\hline
\end{tabular}

Robust standard errors in brackets

* significant at 10\%; ** significant at $5 \%$; ${ }^{* * *}$ significant at $1 \%$ 
Table A5: Table 3 with Alternative Measures of Trend Growth and Volatility

Dependent Variable: Natural log of average decadal capital inflows from Britain

TOT Growth Measure: Varies--see below

TOT Volatility Measure: Varies--see below

Method of construction of trend and volatility measure:

TOT Growth

TOT Volatility

(TOT Growth) x (Exports/GDP)

Exports/GDP

Constant

Observations

R-squared

Decade Dummies

Country Dummies
(1)

HP Filter $(\lambda=300)$ from Table 3

(2) (3)

(4)

\begin{tabular}{cccc}
\hline \multicolumn{4}{c}{$1870-1909$} \\
\hline Core & Periph & Core & Periph \\
\hline & & & \\
0.036 & 0.03 & 1.212 & 0.004 \\
{$[0.372]$} & {$[0.092]$} & {$[0.872]$} & {$[0.152]$} \\
& & & \\
-0.039 & -0.044 & -0.031 & -0.045 \\
{$[0.116]$} & {$[0.024]^{*}$} & {$[0.124]$} & {$[0.025]^{*}$}
\end{tabular}

$-16.977 \quad 0.208$
$[10.847] \quad[0.952]$

[10.847] [0.952]

$20.273-0.041$

[22.264] [3.850]

$\begin{array}{llll}6.576 & 8.236 & 4.461 & 8.252\end{array}$

$[0.722]^{* * *}[0.429]^{* * *}\left[\begin{array}{ccc}2.246]^{*} & {[0.647]^{* * *}}\end{array}\right.$

$\begin{array}{cccc}52 & 84 & 52 & 84 \\ 0.69 & 0.78 & 0.72 & 0.79 \\ Y & Y & Y & Y \\ Y & Y & Y & Y\end{array}$

(5)

(6)

\begin{tabular}{cccc}
\hline \multicolumn{4}{c}{ HP Filter $(\lambda=100)$} \\
\hline Core & Periph & Core & Periph \\
\hline & & & \\
0.007 & 0.019 & 1.288 & -0.025 \\
{$[0.335]$} & {$[0.087]$} & {$[0.764]$} & {$[0.145]$} \\
& & & \\
-0.060 & -0.052 & -0.062 & -0.054 \\
{$[0.129]$} & {$[0.028]^{*}$} & {$[0.135]$} & {$[0.029]^{*}$} \\
& & -18.209 & 0.355 \\
& & {$[9.516]^{*}$} & {$[0.876]$} \\
& & 15.836 & -0.014 \\
& & {$[21.362]$} & {$[3.703]$} \\
& & & \\
6.520 & 9.298 & 4.614 & 9.302 \\
{$[0.573]^{* * *}$} & {$[0.395]^{* * *}$} & {$[2.240]^{* *}$} & {$[0.749]^{* * *}$}
\end{tabular}

\begin{tabular}{cccc}
\hline & & & \\
52 & 84 & 52 & 84 \\
0.69 & 0.79 & 0.73 & 0.79 \\
$Y$ & $Y$ & $Y$ & $Y$ \\
$Y$ & $Y$ & $Y$ & $Y$
\end{tabular}

(9)

(10)

(11)

(12)

TOT Growth Rate and Std Dev of TOT

Growth Rate

\begin{tabular}{cccc}
\hline \multicolumn{4}{c}{$\mathbf{1 8 7 0 - 1 9 0 9}$} \\
\hline Core & Periph & Core & Periph \\
\hline 0.272 & 0.026 & 0.782 & -0.042 \\
{$[0.192]$} & {$[0.060]$} & {$[0.389]^{*}$} & {$[0.117]$} \\
& & & \\
-0.109 & -0.048 & -0.093 & -0.049 \\
{$[0.118]$} & {$[0.043]$} & {$[0.119]$} & {$[0.042]$} \\
& & -7.401 & 0.534 \\
& & {$[4.606]$} & {$[0.626]$} \\
& & 13.177 & -0.088 \\
& & {$[24.774]$} & {$[3.392]$} \\
7.900 & 8.245 & 7.279 & 8.285 \\
{$[1.638]^{* * *}$} & {$[0.509]^{* * *}$} & {$[2.226]^{* * *}$} & {$[0.638]^{* * *}$} \\
\hline
\end{tabular}

\begin{tabular}{cccc}
\hline & & & \\
02 & 84 & 52 & 84 \\
0.71 & 0.78 & 0.73 & 0.78 \\
$Y$ & $Y$ & $Y$ & $Y$ \\
$Y$ & $Y$ & $Y$ & $Y$
\end{tabular}

Robust standard errors in brackets

* significant at 10\%; ** significant at $5 \%$; *** significant at $1 \%$ 
Table A6: Table 3 with Alternative Periphery Allocations

Dependent Variable: Natural log of average decadal capital inflows from Britain

тот Growth Measure: Decadal growth in a Hodrick-Prescott filtered trend

TOT Volatility Measure: Decadal standard deviation of annual departures from trend

Definition of Periphery:

TOT Growth

TOT Volatility

(TOT Growth) x (Exports/GDP)

Exports/GDP

Constant

\section{Observations}

R-squared

Decade Dummies

Country Dummies

\begin{tabular}{cccc}
$(1)$ & $(2)$ & $(3)$ & $(4)$ \\
\hline \multicolumn{4}{c}{ Standard Definition (from Table 3) } \\
\hline \multicolumn{4}{c}{$\mathbf{1 8 7 0 - 1 9 3 9}(\mathbf{1 9 1 0}-1919$ excluded) } \\
\hline Core & Periph & Core & Periph \\
\hline & & & \\
0.036 & 0.03 & 1.212 & 0.004 \\
{$[0.372]$} & {$[0.092]$} & {$[0.872]$} & {$[0.152]$} \\
-0.039 & -0.044 & -0.031 & -0.045 \\
{$[0.116]$} & {$[0.024]^{*}$} & {$[0.124]$} & {$[0.025]^{*}$} \\
& & -16.977 & 0.208 \\
& & {$[10.847]$} & {$[0.952]$} \\
& & & \\
& & 20.273 & -0.041 \\
& & {$[22.264]$} & {$[3.850]$}
\end{tabular}

$\begin{array}{cccc}6.576 & 8.236 & 4.461 & 8.252 \\ {[0.722]^{* * *}} & {[0.429]^{* * *}} & {[2.246]^{*}} & {[0.647]^{* * *}}\end{array}$

$\begin{array}{cccc}52 & 84 & 52 & 84 \\ 0.69 & 0.78 & 0.72 & 0.79 \\ Y & Y & Y & Y \\ Y & Y & Y & Y\end{array}$

\begin{tabular}{cccc}
$(5)$ & $(6)$ & $(7)$ & $(8)$ \\
\hline \multicolumn{4}{c}{ European Offshoots Excluded } \\
\hline \multicolumn{4}{c}{ 1870-1939 (1910-1919 excluded) } \\
\hline Core & Periph & Core & Periph \\
\hline & & & \\
0.053 & 0.074 & 0.489 & 0.020 \\
{$[0.284]$} & {$[0.104]$} & {$[0.502]$} & {$[0.166]$} \\
& & & \\
-0.041 & -0.032 & -0.031 & -0.036 \\
{$[0.102]$} & {$[0.026]$} & {$[0.105]$} & {$[0.028]$} \\
& & -4.720 & 0.613 \\
& & {$[3.477]$} & {$[1.076]$} \\
& & & \\
& & 8.139 & 3.003 \\
& & {$[12.099]$} & {$[4.526]$} \\
9.443 & 6.149 & 8.226 & 6.014 \\
{$[0.543]^{* * *}$} & {$[0.787]^{* * *}$} & {$[2.018]^{* * *}$} & {$[0.825]^{* * *}$}
\end{tabular}

$\begin{array}{cccc}72 & 64 & 72 & 64 \\ 0.76 & 0.74 & 0.77 & 0.75 \\ Y & Y & Y & Y \\ Y & Y & Y & Y\end{array}$

\begin{tabular}{|c|c|c|c|}
\hline (9) & (10) & (11) & (12) \\
\hline \multicolumn{4}{|c|}{ European Periphery Included } \\
\hline \multicolumn{4}{|c|}{ 1870-1939 (1910-1919 excluded) } \\
\hline Core & Periph & Core & Periph \\
\hline $\begin{array}{l}-0.682 \\
{[0.579]}\end{array}$ & $\begin{array}{c}0.144 \\
{[0.106]}\end{array}$ & $\begin{array}{c}-0.686 \\
{[1.159]}\end{array}$ & $\begin{array}{c}0.158 \\
{[0.160]}\end{array}$ \\
\hline \multirow[t]{3}{*}{$\begin{array}{c}0.043 \\
{[0.069]}\end{array}$} & $\begin{array}{c}-0.080 \\
{[0.032]^{\star *}}\end{array}$ & $\begin{array}{c}0.037 \\
{[0.071]}\end{array}$ & $\begin{array}{c}-0.078 \\
{[0.032]^{* *}}\end{array}$ \\
\hline & & $\begin{array}{c}-1.409 \\
{[11.311]}\end{array}$ & $\begin{array}{c}-0.164 \\
{[0.988]}\end{array}$ \\
\hline & & $\begin{array}{c}38.085 \\
{[24.561]}\end{array}$ & $\begin{array}{l}-1.094 \\
{[3.958]}\end{array}$ \\
\hline $\begin{array}{c}5.039 \\
{[1.557]^{\star \star \star}}\end{array}$ & $\begin{array}{c}8.281 \\
{[0.419]^{\star \star \star}}\end{array}$ & $\begin{array}{c}4.491 \\
{[1.739]^{* *}}\end{array}$ & $\begin{array}{c}8.437 \\
{[0.654]^{\star \star *}}\end{array}$ \\
\hline 32 & 104 & 32 & 104 \\
\hline 0.67 & 0.78 & 0.72 & 0.78 \\
\hline Y & $\mathrm{Y}$ & Y & Y \\
\hline $\mathrm{Y}$ & $\mathrm{Y}$ & $\mathrm{Y}$ & $\mathrm{Y}$ \\
\hline
\end{tabular}

Robust standard errors in brackets

* significant at 10\%; ** significant at $5 \%$; *** significant at $1 \%$ 